Öz

Osmanlı Dönemi'nde yangınlar ve depremlerden zarar gören surlar ve sur kapıları yarattıkları tehlike yüzünden onarımlar geçirerek varlıklarını sürdürmüşlerdir. 19. yüzyıl ortalarında batılılaşma süreciyle birlikte belediye örgütünün ilk adımı olarak

“Şehremaneti”nin kurulmasının ardından, örnek daire olarak kurulan 6. Daire'nin bir takım gerekçeler ileri sürmesiyle surlar hakkında yıkım kararı alınmıştır. Surların yıkılması ve sur önlerinde yer alan hendeklerin doldurulmasıyla ortaya çıkacak olan arazinin satılmasıyla Avrupa'daki gibi kâgir yapıların ve geniş yolların yapılması, bölgenin batılı bir görünüme kavuşması öngörülmüștür. Yıkım kararından yaklașık 30 yıl sonra da bu surlar eski eser olarak nitelendirilmeye başlanmış, oldukça tahrip olanların yıkılması ancak iyi durumda olanların korunması kararları alınmıştır.

Surların yıkım sürecini takip etmek için incelenen 19. ve 20. yüzyıl haritalarında, 19. yüzyıl ortasında surların büyük bir kısmının ayakta olduğu; 20. yüzyıl başında ise büyük bir kısmının yıkıldığı anlaşılmaktadır. Yıkım kararının alınmasını takip eden 50 yıllık süreçte, her ne kadar karardan 30 y1l sonra korunması gerekliliği üzerinde durulmuşsa da yıkıldıkları görülmektedir.

Cumhuriyet dönemine gelindiğinde surlardan çok az kalıntı bulunmaktadır.

Menderes Dönemi'nde yapılan geniş caddelerin açılması ve istimlâklar sırasında, bu yolların güzergâhlarında kalan yapılar gibi Kemeraltı Caddesi üzerinde bulunan bir burç da tahrip edilmiştir.

Günümüzde ise "Haliç Metro Geçiş Köprüsü Projesi” için güzergâhta kalan bazı yapılar istimlâk edilerek yıkılmıştır. Bu yıkımlar sonucu ortaya çıkan sur parçalarının istikbalinin ne olacağı belirsizdir.

\section{Abstract}

The ramparts and rampart gates that were damaged by fires and earthquakes during Ottoman Empire period, had been undergone repairs because of the danger that they created, and continued to survive. With the westernization applications in the beginning of 19th. century and after the "Şehremaneti" was established as a first step of municipal organization, the demolition decision for ramparts was taken by 6th. Municipality Department, which was founded as a model department, by asserting some reasons. With the sale of land resulting from demolishing ramparts and filling of trenches located in front of these ramparts, constructing stone buildings and wide roads just like in Europe and attaining a western view of the region were envisaged. Nearly 30 years after the demolition decision, ramparts were began to be qualified as ancient monuments, and decisions were taken to demolish those that were badly damaged while to protect those that were in good condition.

When maps prepared in 19th and 20th century are examined to observe the demolition process of ramparts, it is understood that the ramparts were mostly standing in the middle of 19th century, while they were

1 Bu çalışma, 2008 - 2011 yılları arasında ITÜ Mimarlık Tarihi Yüksek Lisans programinda Prof. Dr. Turgut Saner danışmanlı̌̆ında aynı isimle gerçekleştirilen yüksek lisans tezinden üretilmiştir.

\title{
Galata Surlari'nin
}

Yıkım Süreci

Esra Okur Coşkunçay

Gebze Teknik Üniversitesi Mimarlık Bölümü

\section{Giriş}

Galata bölgesinin tarihi binlerce y1l öncesine dayanmakta olup, bu bölge ilkçağda "Sykai" olarak adlandırılmış ve I. Konstantin (324-337) tarafindan bir sur duvarı ile kuşatılmıştır. II. Theodosius (408-450) devrinde ise, Konstantinopolis şehrinin bölgeleri düzenlendiğinde 13. "Regio" olarak kente bağlanmıştır (Eyice, 1969). Bu surlar I. Iustinianus (527-565) döneminde yenilenmiştir (Müller-Wiener, 2007). Bölgenin 14. yüzyılda Cenevizlilere verilen bir imtiyaz bölgesi olmasıyla birlikte surlar 15. yüzyıl ortasına kadar kademeli inşa edilerek son haline ulaşmıştir (Resim 1, Resim 2).

Galata surları, sur içi şehir kurgusu ile ihtiyaç doğrultusunda zamanla genişleyen bir tahkimat sistemiyle ortaya çıkmıştır. Ortaçağda sınırları belirleme ve güvenliği sağlama temel ilkeleriyle inşa edilen surlar, 19. yüzyıla kadar sıkışan yapı adalarının arasında büyük ölçüde ayakta kalabilmiştir. Bu çalışma, 19. yüzyılda Tanzimat sonrası uygulanan batılılaşma hareketleri doğrultusunda Galata surlarının yıkım sürecinin ortaya çıkarılması amacını taşımaktadır.

Çalışmada Galata surlarının yıkımlarının İstanbul'da bulunan Başbakanlık Osmanlı Arşivi'ndeki belgeler taranarak izlenmesi hedeflenmiştir. Böylece devletin resmi belgeleri üzerinden surlarla ilgili yıkım kararının ne zaman alındığı, karar öncesi ve sonrası ne gibi gelişmeler yaşandığı tespit edilmiştir. Bu belgeler dişında 19 . yy. ve 20. yy'da Galata bölgesini içeren haritalar da inceleme kapsamına alınmış, bu haritalarda surlar zaman içinde hangi ölçüde ayakta kalmış, hangi ölçüde yıkılmış takip edilmeye çalışılmıştır. İncelenen haritalar üst üste çakıştırılarak surların yıkım süreciyle ilgili harita çıkarılmıştır'.

\section{Başbakanlık Osmanlı Arşivi Belgelerinde Galata Surlart}

15. yüzyıl ortasında son şeklini alan Galata surları, bölgenin Osmanlı himayesine girmesiyle bir miktar alçaltılmıştır. 16. yüzyıl ortalarından başlayarak giderek harap olan surların üzerlerine ya da yerlerine, 18. yüzyıl başından itibaren devlete verilecek bir bedel karşı1lığında ev yaptırılmasına müsaade edilmesi 1712'ye tarihlenen bir belgeden anlaşılmaktadır (Eyice, 1969).

Surların ve sur kapılarının onarımları ile ilgili kararlar Başbakanlık Osmanlı Arşivi'nde yer alan belgelerden öğrenilmektedir. 6. Belediye Dairesi'nin 1857 yılında kurulmasının ardından, belediye gelirlerinin arttırılması ve bölgenin batılı bir görünüme kavuşturulması amacıyla 1863 yılında surların yıkılarak arazilerinin ve hendeklerinin satılması kararı alınmış; 
ancak bu karardan yaklaşık otuz yıl sonra surların tarihi bir değere sahip olduğu belirtilerek sağlam parçalarının korunması gerekliliği üzerine yazışmalar yapılmıştır (Resim 3).

\subsection{Galata Surlarındaki Onarım Çalışmaları}

\subsubsection{Tehlikeli Olduğundan Ylkılan Sur Duvarlart ve Kapılart}

22 Mayıs 1766 yılında İstanbul'da meydana gelen büyük depremden şehirdeki pek çok yapı gibi Galata surlarının da etkilendiği, Osmanlı arşivinde yer alan 08.06.1766 (H. 29 Zilhicce 1179) tarihli ve deprem nedeni ile yıkılmaya yüz tutmuş ve tehlike arz eden sur parçalarının Mimarbaşı Mehmet Tahir tarafından belirlenerek yıkılması ve maliyetinin kendisine ödenmesi konulu belgeden öğrenilmektedir (BOA, C.BLD., 134, 6675). Çıkarılan bu ferman sonrasında Mimar Mehmet Tahir, Galata'da yer alan Kürkçü Kapısı ile Azap Kapısı arasındaki beş adet tabyanın (savunma yapılarının) üst k1sımlarındaki bazı bölgelerin; bu kısımlar arasındaki kale duvarlarının yukarısında yer alan yelkenci ve demirci aletlerinin bulunduğu gemi dükkânlarının tehlike yaratacak boyutta yıkılmak üzere olduğunu, buraların boşaltılarak yıkılması gerektiğini belirtmiştir. Yazışmalara, bölgede yıkılması gereken yerlerin belirtildiği defter eklenmiş, yıkım işlemi için 338 kuruş istenmiştir. İletilen defterin incelenmesinin ardından yıkım işlemleri Başmuhasebe tarafından 336, 5 kuruş olarak hesaplanmış, miktarda
36, 5 kuruşluk bir azaltma yapılarak Mimar Tahir'e belirtilen bölgelerin yıkım işlemleri için 300 kuruş ödenmesine karar verilmiştir.

\subsubsection{Sur Kapıları Onarımları}

19. yüzyılda Galata surlarının artık hiçbir işlevsel niteliği kalmamasına rağmen, surlarda yer alan bazı kapıların ve kemerlerinin onarıldığı belgelerden öğrenilmektedir.

Araştırılan arşiv belgelerinde, Karaköy Kapısı ile ilgili bir çok dosya bulunmaktadır. Bunlardan ilki 08.12.1796 (H. 07 Cemaziye'l-ahir 1221) tarihli Karaköy Kapısı'nın tamir edilmesi konusunda yazışmaların yer aldığ 1 dosyadır (BOA, C.BLD., 141, 7020). Bu yazışmalarda kapının oldukça kötü durumda ve yıkılma tehlikesiyle karşı karşıya olduğu belirtilmektedir. Tamiri ve yenilenmesi için ismi belirtilmeyen bir mimar tarafından hazırlanan keşif defterinde masif kalkan duvarı, söve, demir milli kapı, horasanlı sıva, asma kilit gibi işlemler ve işçilikler için 500 kuruş maliyet çıkarıldığı bildirilmektedir. Bu ücretin Galata Voyvodası'na verilerek kapının tamir işlerinin Voyvoda tarafından yapılması önerilmiştir. Bunu önermelerine dayanak olarak, birkaç sene önce Karaköy Kapısı'nın yanındaki duvar yıkıldığında Galata Voyvodası'nın dükkan sahiplerinden yapım masrafını alarak duvarı yaptırdığı gösterilmektedir. Bu kapının civardaki dükkan sahiplerince onarılması durumunda ise maliyetinin 500 kuruştan daha fazla olacağı öngörülmüştür. mostly demolished in the beginning of 20th century. During the 50 years period after the demolition decision was taken, it is seen that ramparts were demolished although the protection was mentioned 30 years after the demolition decision.

By the period of the republic, very few remnants were left over from Galata ramparts. During the expropriations and constructions for boulevards in Menderes period, a bastion on the Kemeralt Street had been destroyed just like other buildings on the route of these roads.

Nowadays, some buildings on the route for "Haliç Subway Transit Bridge Project" are expropriated and demolished, and the future of rampart pieces which are left over after demolition is uncertain.

Anahtar Kelimeler: Galata, Galata Surları, Ceneviz Surları, Sur Yıkımları, Surlar Keywords: Galata, Galata Ramparts, Genoese Ramparts, Demolition of Ramparts, Ramparts

Resim: I

Galata bölgesinin farklı dönemlerdeki siyasi ve fiziki durumu (Harita: MüllerWiener, 2007, düzenleme: Esra Okur Coşkunçay)

Resim: 2

Schneider ve Nomidis'in 1944 tarihli Galata Haritası - Galata surları ve gelişim dönemleri (Osmanlı Bankası Arşivi, Düzenleme: Esra Okur Coşkunçay)
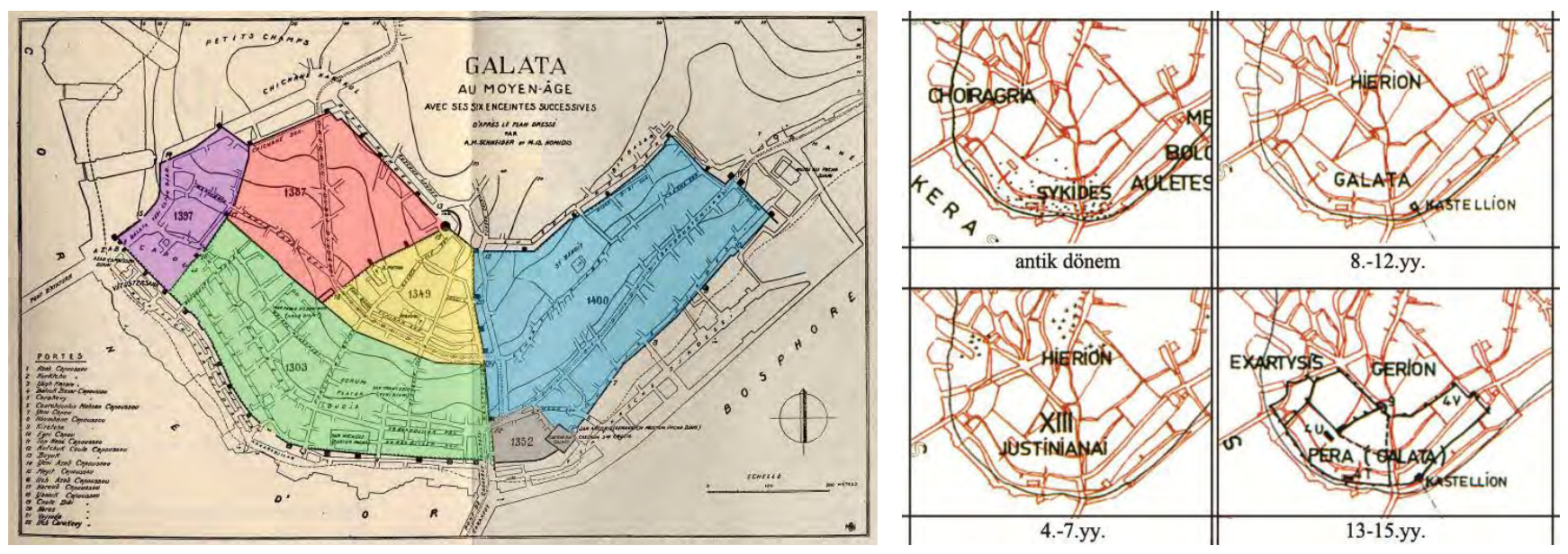


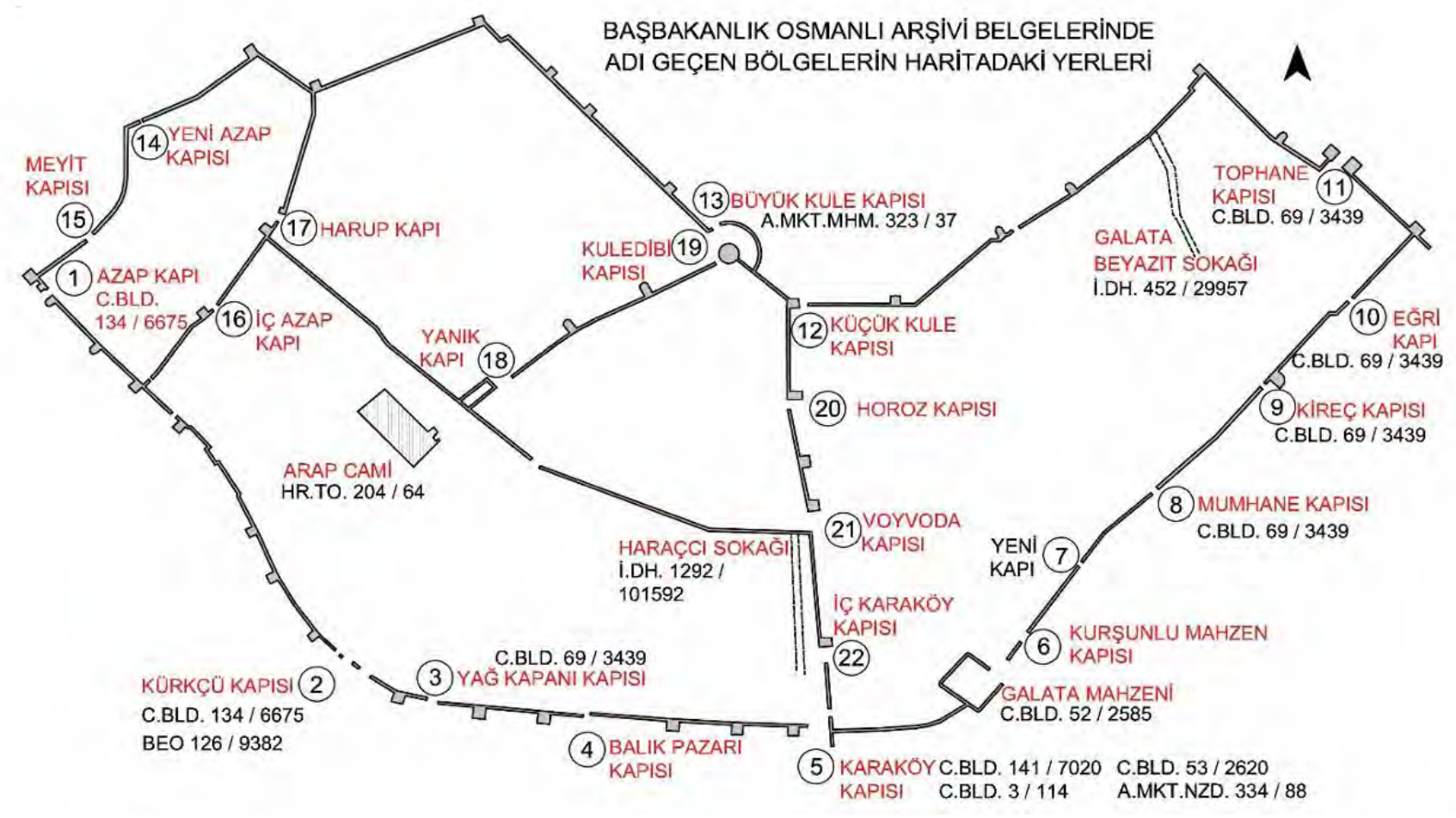

Resim: 3

Başbakanlık Osmanlı Arşivi belgelerinde adı geçen bölgelerin 1944 tarihli schneider ve Nomidis'in Galata surları haritası üzerindeki yerleri (Osmanlı Bankası Arşivi, Düzenleme: Esra Okur Coşkunçay).
Karaköy Kapısı'nın tamiriyle ilgili bir başka dosya da 15.09.1810 (H. 01 Rabiu'l-ahir 1241) tarihinde düzenlenmiştir (BOA, C.BLD., 3, 114). Kapı kemerinin çıkan bir yangın sonucu yandığ 1 ve bazı kısımlarının harap, bazı taşlarının da yerlerinden ayrılmış olduğu belirtilmiştir. Kapının konumunun padişahın kullandığı bir güzergahta ve işlek bir yerde olduğu vurgulanmış; acilen onarılması konusu Galata Voyvodası tarafından Hassa Mimarbaşı'na bildirilmiştir. Yapılan keşif sonrasında kapı kemerinin durumunun tehlikeli olması yüzünden harçla kargir inşası, demir edevatı, kullanılmamış battal keresteden parmaklık kapı inşası, bazı zedelenmiş duvarların tamirlerinin masrafının 314 kuruş olacağ 1 Mimarbaşı tarafından düzenlenen defterde ayrıntılı olarak anlatılmıștır. 275 kuruşun kapının onarımı için Mimarbaşına verilmesi, 39 kuruşun da vergi olarak alınması Başmuhasebe'ye bildirilmiştir.

25.04.1805 (H. 25 Muharrem 1220) yilında Nöbethane ve Galata Kalesi'nin köşelerinin tamiri için gerekli ücretin verilmesi konusunu içeren bir belgede, bu yapıların köşelerinin tamiri için iki senede bir 110 kuruş verildiği belirtilmiş, aynı yıl da yine onarımların yapılabilmesi için gerekli ücretin Başmuhasebe'ye bildirilerek ödenmesi istenmiştir (BOA, C.BLD., 52, 2585).

Bölgede zaman zaman çıkan yangınlardan Galata surları ve kapıları da zarar görmektedir. 04.03.1840 (H. 29 Zilhicce 1255) tarihli bir belgeden Tophane Kapısı ve Yağkapanı Kapısı'nın da onarılmasıyla ilgili bir keşif defteri çıkarıldığı öğrenilmektedir (BOA,

C.BLD., 69, 3439).

\subsubsection{Yıkılması veya Yeniden Yapılması Gündeme Gelen Sur Kapıları}

Surların ve kapıların onarımları için zaman zaman çalışmalar yapılsa da, özellikle kullanılamayacak durumda olan kapıların ya tamamen yıkılması ya da y1kılarak yeniden yapılması konuları gündeme gelmiştir.

01.02.1835 (H. 02 Şevval 1250) tarihli bir belgeden, yine Karaköy Kapısı dahilinde ismi belirtilmeyen bir kapının kemer taşlarının onarımının oldukça masraflı olduğundan yıktırılması veya eskisi gibi inşa ettirilmesi gerekliliği konusunun ele alındığı öğrenilmektedir (BOA, C.BLD., 
53, 2620). Bu belgede bahsedilen kapının kemer taşlarının yer yer düşmekte olduğu ifade edilmiş, Müdir-i Ebniye-i Hâssa Efendi'nin (Baş Bina Müdürü) kapıyı kontrol etmesinin ardından bu kapının tarihi bir kapı olduğu belirtilmiştir. Yan yana iki adet kemeri olan bu kapının bir yangın sonrasında tamir edilmesine rağmen zamanla taşlarının döküldüğü, kemerlerden birinin tamamen yıkıldığ 1 , diğer kemerin de taşlarının düşmekte olduğu ve tehlikeli bir durum yarattığı bildirilmiştir. Kapının kullanılır ve işe yarar bir kapı olmaması; özellikle tamirinin oldukça masraflı olması yüzünden tehlike arz eden bu kapının ya tamamen kaldırılması ya da eski usulüne göre yeniden yapılması konusunda üst makamlara danışılmıştır.

6. Daire'nin kurulmasının ardından yapılan imar çalışmalarında Karaköy Kapısı'nın 1858 yıllarında yıkıldığı, Karaköy Kapısı'nın işsiz kalan eski kapıcısı Mehmet isimli kişiye maaş bağlanması konusunun görüşüldüğü 11.12.1860 (H. 27 Cemaziye'l-evvel 1277) tarihli belgeden anlaşılmaktadır (BOA, A.MKT.NZD., 334, 88). Belgede, uzun zamandir kapicılık yapan Mehmet adlı kişinin kapının iki sene önce yıkılmasıyla işsiz kaldığı ve borçları yüzünden mağdur olduğu bildirilmiştir. Kapıcı bu durum üzerine dilekçe ile kendisine maaş bağlanması isteğinde bulunmuş, sadece 200 kuruş tazminat verileceğini öğrendikten sonra verilecek bu miktar ile geçinmesinin mümkün olmadığını belirtmiştir. Geçimini temin etmek için üç ay sonra inşa edilecek kapının kapıcılarının yerleștirileceği mahalleye kendisinin yerleştirilmek istediğini, bu sağlanamazsa masrafları için kendisine yeterli maaşın bağlanmasını ve bu durumun çözümlenmesini dilekçesinde arz etmiștir.

Daha önce bahsedilen 04.03.1840 (H. 29 Zilhicce 1255) tarihli arşiv belgesinde Tophane Kapısı ve Yağkapanı Kapısı'nın da onarılmasının yanında, bölgede çıkan yangından ötürü oldukça hasarlı durumda bulunan Kireçkapısı, Eğrikapı ve Mumhane Kapısı'nın yeniden yapımı gündeme geldiği öğrenilmektedir (BOA, C.BLD., 69, 3439).

\subsubsection{Sur Kapıları Bekçileri}

Sur kapılarının 19. yüzyılda da bekçiler tarafından kontrol altında tutulduğu 26.03.1838 (H. 29 Zilhicce 1253) y1lında Seraskerat'a yazılan bir belgeden anlaş1maktadır (BOA, HAT, 679, 33114A). Galata Kadısı'nın bildirmesi üzerine surlarda yeni açılan iki kapıya iki kapıcının atanması öncelikle Tophane-i Amire Kumandanı'na iletilmiş, ancak yörede oturan askerlerden uygun birilerinin bulunamadığ 1 belirtilmiştir. Bu sebeple Seraskerat tarafından uygun görülen kimselerin tayin edilmesi, çıkarılan bir Hatt-1 Hümayunla bildirilmiştir.

\subsubsection{Sur Üzerinde Kapı Açılması}

19. yüzyılda onarılan, y1kılan ve yeniden yapılan sur kapılarının yanında yeni kapıların da açılması 19. yüzyılda gündeme gelmiştir.

6. Belediye Dairesi Meclis üyeleri Sadaret Makamı'na 09.09.1859 (H. 11 Şaban 1276) tarihinde Bayezid Mahallesi civarında bir kale kapısı açılması yönünde bir yazı göndermiştir (BOA, I.DH., 452, 29957). Bu yazıya göre Bayezid Mahallesi sakinleri buradaki sur duvarında bir kapı açılmasını istemişlerdir. Bu kapının açılmasıyla Galata Caddesi'nden Beyoğlu'na kadar düzgün bir hat üzerinde, 8 arşın $(6.5 \mathrm{~m}$.) genişliğinde büyük bir araba yolu oluşacağı, bunun dilekçeyle verilen haritadan anlaşılacağı bahsedilmiştir. Ancak bu harita dosyada yer almamaktadır. Oluşturulacak bu araba yolunun hem şehre hem de halka çok fayda getireceği üzerinde durulmuştur. Bu yeni kapının bölgedeki diğer kapılar gibi akşamları kapatılmak üzere bir demir parmaklığı olacağ1 bildirilmiştir. Ancak bu kapının açılacağı sur önündeki hendek alanında yapılmış üç adet lüleci dükkânının bulunduğu belirtilmiş, açılacak kapı ve yol üzerinde kalan bu dükkanların yıkılması gerektiği ifade edilmiştir. Dükkanları yıkılacak mülk sahiplerine, civarda başka dükkânlar verilmesi konusunun Ticaret Nezaret-i Celilesi (Ticaret Bakanlı̆̆) tarafından bir sonuca bağlanması gerektiği hususlarını belirterek dilekçelerini sonlandırmışlardır. Verilen dilekçe Meclis-i Tanzimat tarafın- 
dan olumlu değerlendirilmiş ve Sadaret'e iletilmiştir. Dilekçe padişah tarafından uygun bulunarak gerekenin yapılması konusunda gerekli izin verilmiştir. Dönemin Vakanüvisi Ahmed Lütfi Efendi 6. Daire Meclisi'nin aldığı bu kararı eleştirmektedir (Aktepe, 1984).

\subsection{Belediye Dairesi'nin Kurulması ve Galata Surlarının Yıkılması}

İlk kez 19. yüzyılda inşaat hareketlerinin düzenlenmesiyle, 1831'de "Şehremini" makamı ortadan kaldırılarak "Ebniye- i Hassa Müdürlüğ̈̈”, 1849 yılında da "Sadaret Nezareti" kurulmuştur (Kuban, 2004). 16 Ağustos 1855 y1lında Takvim-i Vekayi “Ihtisab Nezareti”"nin lağvedildiğini ilan etmiştir (Toprak, 1994). "Dersaadet ve Bilad-1 Selase" de denen Galata, Eyüp ve Üsküdar Şehremaneti kurulmuştur (Genim, 2004). Fransız modeline uygun olarak kurulan Şehir Belediyesi anlamında "Şehremaneti", belediye işlerinden sorumlu Ihtisab Nezareti yerine kurulmuştur ve bu girişim Tanzimat reformlarının oluşturduğu kurumların ilki sayılmaktadır (Öncel, 2010). Şehremaneti'nin kurulması, belediye örgütünün ilk adımı sayılmaktadır (Akın, 2002).

$\mathrm{Bu}$ girişimden sonra ise 1856 yılında tamamen yeni bir kurum olan "İntizam-1 Şehir Komisyonu" kurulmuştur (Öncel, 2010). Bu kurumun iki y1l süreyle yaptığ 1 çalışmalar sonrası sunduğu rapor, kentin istenilen düzeyde bir yerleşme olabilmesi için yapılması gerekenleri içermektedir (Akrn, 2002). Komisyonun önerilerinden biri şehri 14 alana bölerek, Galata, Pera ve Tophane'yi içine alan bölgede 6. Belediye Dairesi adı altında ilk belediye girişimini başlatmaktır. Komisyonun tüm önerileri kabul edilmiş ve 6. Belediye Dairesi'nin kuruluşu 1857 yılında Resmi Gazete'de ilan edilmiştir (Öncel, 2010). Kentin 14 bölgeye bölünmesi Konstantin döneminin 14 bölgesini anımsatır.

Örnek bir daire olarak kurulan 6 . Daire'nin sorumluluk alanının bu bölge seçilmesinin nedeni, bölgede değerli taşınmazların bulunması ile kentin bu bölgesinde oturanların Avrupa'da bu tür belediye hizmetleri gördükleri için reformlara sicak bakacakları umudu olmuştur. Paris'te sixiéme arrondissement diye bilinen belediye biriminin kentin en etkin donanımına sahip bölgesi olması, Galata-Pera bölgesinin 6. Daire adını almasının nedeni olarak düşünülmektedir (Toprak, 1994).

Dairenin yetki alanı Kasımpaşa ile Pangaltı arasındaki bölgeyi, Dolmabahçe ile Haliç'teki tersane arasındaki k1yılar dâhil olmak üzere Harbiye'den Dolmabahçe'ye kadarki alanı kapsamaktadır (Kuban, 2004). 19. yüzy1l modernleşme sürecinde batılı örneklerden model alınarak oluşturulan kurumlardan biri olan 6 . Daire Belediyesi, 1876 yılında belediyeler kanununun ilan edilmesine kadar ayricalıklı statüsünü korumuştur (Öncel, 2010).

Dairenin yaptığı ilk uygulama yetki bölgesinin kadastro çalışmalarını yapmak olmuştur (Genim, 2004). Dairenin görevi cadde, sokak ve kaldırımları bakımlı hale getirmek, suyollarını ve lağımları düzenlemek, bölgenin temizliğini sağlamaktır (Akin, 2002). Ayrıca sokakların aydınlatılması da görev alanındadır. 1858 Nizamnamesi ile belediye sınırları içindeki tüm yapıların değerleri, inşaat tarzı, sahiplerinin isimlerini de içermek üzere kayıt yapma görevi de 6. Daire'ye verilmiştir (Toprak, 1994).

6. Daire'nin bölgedeki yenileme girişimlerinden biri 1858 yılından başlayarak Galata Köprüsü’nün Galata tarafındaki yeni Karaköy Meydanı'nın planlanması, bölgenin kamulaştırılması ve projenin uygulanması olmuştur. Bu meydan eski Ceneviz Meydanı'nın olduğu bölgeye denk düşmektedir (Kuban, 2004). 1861 yılına gelindiğinde Belediye, kentsel düzenleme açısından önemli çalışmalarda bulunmuştur. Galata'da yolların genişletilmesine ve havagazıyla aydınlatılmasına, eski Ceneviz yapılarının yıkılmasına ve yıkılan yapilarin yerlerine daha modernlerinin yapılmasına başlanmıştır (Akın, 2002).

Öte yandan, yatırımları olduğundan saygınlık kazanan yabancılar ilk defa kent yönetimine etkin bir biçimde katılmaktaydılar. Yabancılardan alınacak borç ile hükümetin maddi 
imkânlarını aşan 6. Daire'nin projeleri uygulanabilecekti (Çelik, 1996). Ancak yöre zenginlerinden yapılacak uygulamalar için alınması düşünülen borç da istenildiği gibi gerçekleştirilememiştir. Belediyenin kasasına girmesi için Karaköy Köprüsü geçiş ücretlerinin arttırılması ve belediye masraflarında kısıntı yapmak amaciyla da personel sayısının azaltılması gibi uygulamalar yapılmıştır (Akın, 2002).

6. Daire gelirlerini arttırmak amaciyla daha farklı yollara da başvurmuştur. Galata surundan bazı mahalleri yıkarak üzerine bina inşa etmiş ve bu alanları kullanmakta bulunanlardan bedelinin alınması ile Kule-i Zemin Müsakkafatı'nın da (sur kenarindaki mülkler) taliplerine satılması konulu bir dosya 20.11.1863 (H. 08 Cemaziye'l-ahir 1280) tarihiyle Osmanlı arşivinde yer almaktadır (BOA, $M V L ., 857$, 82). Bu dosyada yer alan yazıșmalarda, yıkılan surların yerlerine yapı yapmıș olanlardan ve buraları kullananlardan padişah emriyle arazi bedellerinin tahsil edilmesi ve bu arazilerin Kule-i Zemin Komisyonu'nun araştırması sonucu isteklilerine satılması çalışmasının yürütüldüğü bildirilmiştir. 6. Daire emlak defterlerinden her bölgenin değerinin araştırıldı̆̆ 1 belirtilerek, bunun gibi gasp edilmiş mülklere de değer biçilmesi ve bedellerinin sahiplerinden toplanılması için Evkaf-1 Hümayun'dan (Padişah Vakfindan) senet düzenlenmesi, komisyondan da geçici birer senet verilmesine karar verildiği belirtilmiştir.

Bu kararın hemen ardından düzenlenen "Galata surlarının y1kılması" iradesini içeren bir dosya 30.11.1863 (H. 18 Cemaziye'lahir 1280) tarihiyle karșımıza çıkmaktadır (BOA, I.MVL., 497, 22492). Bu dosyadaki 21.10.1863 (H. 08 Cemaziye'l-evvel 1280) tarihli Vekâlet-Penahî’ye (Başbakanllk) yazılan ilk belgede, Kule-i Zemin Vakfi arazisinden ve asıl kale duvarından bazı kimselerin yıktığ 1 ve izinsiz olarak hane ve mağazalarına ilave etmiş oldukları yerlerin padişah emri gereği Nafia Nezareti (Bayındirllk Bakanllğl) dairesinde oluşturulan komisyon tarafindan bedellerinin toplatıldığ 1 bildirilmiştir. Ancak Galata'da bulunan kale duvarlarının çoğunun içten ve dıştan han ve hane ile kuşatıldı $\breve{g}_{1}$, bu sebeple kale duvarının bazı bölümleri terk edilmiş ve işe yaramaz bir vaziyette kalmış olduğu ifade edilmiștir. Komisyona çağrılan bu mülk sahiplerinden bazıları adı geçen sur parçalarından kendilerine lazım olan yerlerin satılmasını, bazıları duvarlara kapı açılmasına izin verilmesini, kimisi de satın aldıktan sonra bu surları yıkarak hâlihazır bulunan binasına bu alanların eklenmesini istemişlerdir. Bu istekler doğrultusunda terk edilmiş ve işe yaramaz bir şekilde kalan bu sur parçalarının, uygun bir peşinatla isteklilere satılması ve bazı dar sokakların da bu duvarların yıkılmasıyla genişletilmesi durumunun düşünüldüğgü belirtilmiştir. Belgenin sonunda ise Padişah emrindeki heyetin, Kule-i Zemin arazisindeki mevcut olan hisarların satışı konusuna bir açıklık getirmediklerinden, bu konuda Sadaret'in görüşlerine başvurmuşlardır.

Dosyada yer alan diğer belge 4.11.1863 (H. 22 Cemaziye'l-evvel 1280) y1linda Meclis-i Vâlâ-yı Ahkâm-1 Adliye tarafından yazılmıştır. Kule-i Zemin bölgesinin, aslen Galata surunun top altı menzilinde terk edilmiş yerler olduğunu, ancak zamanla durumunun değiştiğini, bölge ve mekân olarak bu yerlerin ne şekilde kime geçtiği ortaya çıkarıldıktan sonra bunların değerleri komisyon tarafından padişah emri ile hak iddia edenlerden temin edileceği belirtilmiştir. Şimdiki durumu gereğince, Galata Kale duvarının kesinlikle hükmünün kalmadığı, özellikle bu duvardan vaktiyle açılmış olan ve üzerine bina yapılan birçok yerin değerleri usulüne uygun olarak toplatıldıktan sonra sahiplerinin hakları sağlanmış olacağı ifade edilmiştir. Ancak mülk sahiplerinden kullandıkları bölgelerin bedellerinin alınması sonrasında, aralarda kalacak duvarların bir takım mülk sahiplerince gasp edileceği tahmin edilmiştir. Bu yüzden bu surun açıklanan durumuyla beraber işe yarar olmaması sebebiyle, surların yıkılarak arazinin de isteklilerine satışının yapılabileceği; bu satış sayesinde de peşin alınan paradan ve sur taşlarından pek çok akçe elde edilerek bu yıkımın yararının 
artacağından bahsedilmiştir. Böylece hazinenin çok fayda göreceği, bunun gibi meydana çıkacak yerlere binalar yapılarak buraların imarının yapılarak sokakların genişletilebileceği ifade edilmiş; komisyonun sunulan görüşleri yolunda ve uygun görülmüştür. Eğer gerekenin yapılmasına izin verilirse, Komisyon vasitasiyla Nafia Nezareti'ne (Bayındirlkk Bakanlığ) bu kararın uygulanmasının iletileceği belirtilmiştir. Danıştay üyelerinin mühürleri ile belge sona ermektedir. Meclis-i Vâlâ'nın yolladığı rapor 1.12.1863 (H. 19 Cemaziye'lahir 1280) tarihinde Sadaret'e iletilmiştir. $\mathrm{Bu}$ rapor padişah tarafindan görülmüş; Galata surlarının komisyon kontrolünde yıkılarak arazisinin ve taşının satılması konusunun Nafia Nezareti'ne iletilmesi padişah tarafından 12.12.1863 (H. 1 Receb 1280) tarihinde uygun bulunmuştur.

6. Belediye Dairesi'nin çabalarıyla Galata surlarının yıkılması kararı alındıktan sonra, bölgede kentsel değişiklikler gerçekleşmeye başlamıştır. Üzerinde inşaat yapılabilecek satılık alanlar, surların yıkımı ve ve hendeklerin doldurulmasıyla oluşturulmuştur. Bu alanların satışından elde edilecek gelir Belediye'nin bütçesini bir ölçüde rahatlatmaktadır (Öncel, 2010).

Sur yıkım süreciyle ilgili Osmanlı Arşivi’nde yer alan başka bir dosya da 04.02.1864 (H. 25 Şaban 1280) tarihli "Galata Haracı Sokağı'ndaki mağazalara yıkılan kale duvarlarından yapılan ilaveye karşılık olarak, gasbedilmiş yerler için belirlenen kiymet takdiriyle para talebinde bulunulması mağaza sahiplerinin mağduriyetine sebep olduğ u" başlıklı bir dosyadır (BOA, I.DH., 1292, 101592). Dosyadaki 14.12.1863 (H. 03 Receb 1280) tarihinde Nafia Nezareti'nin (Bayındırlk Bakanlığl) Vekâlet-Penâhî’ye (Başbakanlık) göndermek üzere yazdığ1 dilekçede, Kule-i Zemin Vakfı arazisinden bazılarının dükkânlarına ilave edip senetsiz kullanmakta oldukları yerlerden Galata tarafinda bulunan yerlerin komisyon tarafından gerçek değerleri belirlendiği, Galata Haraççı Sokağı'nda bulunan mağazaların arkalarında bulunan kale duvarlarının boydan boya yıkılıp ilave edildiği ifade edilmiştir. Komisyona götürülen bazı mağaza sahiplerinden, kale duvarından almış oldukları yerlerin bedelleri istenmiş̧ir. Ancak bahsedilen Haraççı Sokağı'nın 1, 5-2 (1-1.5 m.) arşından ibaret oldukça dar bir yol olduğu, 6 . Daire tarafından bu yolun genişletilmesi için mağazaların yarısının ya da daha fazlasının yol genişletilmesi için sokağa katılmış ve buna karşılık arkalarında bulunan kale duvarlarının yıkımıyla mağazalarına ilavesine müsaade edilmiş olduğunun bildirildiği belirtilmiştir. Bu durumda bu almış oldukları yerlerin gasp olunmuş gibi sayılarak ellerinden alınması ve para talebinde bulunulması durumunda mağdur duruma düşecekleri düşünülmüştür. Bu mağazalardan sokağa terk ettirilen yerlerin, benzerlerine nazaran daha fazla olduğu bildirilmiştir. Ayrıca, Daire tarafından mülk sahiplerine açıkça sur duvarlarının yıkımı konusunda bir emir ya da izin verilmemiş olduğu kabul edilmiş; ancak mülk sahipleri bu duvarları yıkarken Dairenin de buna engel olmadığ 1 iddia edilmiştir. Yolların genişletilmesi için Daire tarafından yapılan haritada sur duvarlarının mağazalara ilave edilmiş bir biçimde gösterilmesi ile bu iddiaların doğruluğu belirtilmiştir. Bahsedilen yolun genişletilmesinin orada bulunan mağazalara fayda getireceği; bununla birlikte bu mağazalara kale duvarından ilave edilen bölgelerin değerinin tam olarak alınmak istenmesinin uygun ve adaletli olamayacağ1 düşünülmüştür. Mülk sahiplerinden istenilen ücretlerden tamamıyla vazgeçilmesinin de mümkün olmadığının bilindiği ifade edilmiştir. Gerek bu kimselerden, gerekse bunun gibi diğer mülk sahiplerinden alınması gereken ücretten yüzde 35 düşüldükten sonra, yalnız bunlara mahsus olmak üzere kalanın dörtte birinin terk edilmesi ve ücretlerin bu şekilde indirilmesinin görüşüldüğü ve onaylanmış olduğu; bu durumun uygun, insaflı ve adaletli bulunduğu belirtilmiştir. Bedellerin tahsilâtının bu şekilde yapılması için Vekâlet-Penâhî’den izin istenmiştir. Nafia Nezareti'nin yazmış olduğu bu dilekçe Meclis-i Ahkâm-1 Adliye tarafından, 06.01.1864 (H. 26 Receb 1280) tarihinde durumu açıklayan başka bir yazı bir üst 
makama gönderilmiş; 31.01.1864 (H. 21

Şaban 1280) tarihinde ise Vekâlet-Penâhî̀ye sunulan dilekçe sonrasında, bahsedilen konunun görüşüldüğü ve izin istendiği üzere gerekenin yapılması konusunda 01.02.1864 (H. 22 Şaban 1280) tarihinde padişah fermanı verilmiştir.

6. Daire'nin Galata surlarının yıkım kararını onaylatmasıyla 19. yüzyılın ikinci yarısına kadar ayakta kalabilmiş olan bu surlarla ilgili çalışma yapan Marie de Launay’nin “Galata Surlarına İlişkin Notlar"' adlı makalesi 1, 2 ve 5 Aralık 1864 yılında kentte çıkarılan Journal de Constantinople gazetesinde yayımlanmıştır. Bu makalenin yanı sıra Galata surlarının bu dönemde mevcut durumunu gösteren bir harita hazırlamıştır (Şekil 12).

Launay (1864a), 1 Aralık gününe ait Journal de Constantinople gazetesinde Galata surlarına ait bazı teknik bilgiler vererek makalesinin ilk bölümüne başlamaktadır. Makalede, yapılacak yol inşaatı çalışmaları nedeniyle takviye edilmiş ancak yakında tamamen yok olacak surların neredeyse yıkılmak üzere olduğunu belirtmiştir. Galata surlarının dörtte birinin antik yapı kalıntısı da olan mermerle ve geri kalanının da orta büyüklükteki moloz taşlarla karıştırılarak inşa edildiğini ifade ederek, kalınlığının yaklaşık 3 arşın (2, 25 m.) olduğunu bildirmiştir. Kuruluşundan itibaren gözcü yeri olarak kullanılmış büyük kuleden başlayarak tüm şehri çevreleyen ilk surun 3.700 arşın (yaklaşılk $2.800 \mathrm{~m}$ ) uzunluğunda ve dağınık bir biçime sahip olduğunu anlatmıştır. Dört başka surun daha varlığından bahsederek bunların daha az önemli olduğunu ve bu surların da ana sur tarafından çevrelendiğini vurgulamıştır. Ayrıca ana surun, Galata Kulesi diye adlandırılan büyük İsa (Christ) Kulesi ile birlikte 24 kulesi olduğunu, bu kulenin avlu bitiminde yükselen yarım çember biçimli Kule Kapısı'nın da bulunduğu toplam 42 kapısı olduğu konusunda bilgi vermiştir. Pera yönünde, önceleri surları çevreleyerek korunan ortalama $15 \operatorname{arşın~}(20 \mathrm{~m}$.) genişliğinde ve o dönem neredeyse tamamı yıkılmış olan bir hendek bulunduğunu belirtmiş, deniz tarafındaki surlarda bulunan 12 kuleden her birinin aralarındaki uzaklığın yaklaşık 44 arşın (33 m.) olduğunu bildirmiş̧tir.

Launay (1864a), aynı günkü gazetede yer alan makalesinde, Ceneviz şehri olan Galata'nın toplam $369.137 \mathrm{~m}^{2}$ lik bir alan kapladığını, bu alanın 37 hektar ya da 410 dönüme tekabül ettiğini belirterek, ara surların oluşturduğu alanları da şu şekilde özetlemektedir:

- Tarlabaşı Mezarlı̆̆ Üstüpçüler Sokak ve Yolcuzade Sokakları arasında uzanan ilk sur: 56.355 arşın kare $\left(31.700 \mathrm{~m}^{2}\right)$,

- Yolcuzade Sokak, Perşembe Pazarı, Hendek ve Yeni Kapı arasında uzanan ikinci sur: 111792 arşın kare $\left(62.883 \mathrm{~m}^{2}\right)$,

- Perşembe Pazarı, Yeni Kapı, Yolcuzade, Fermeneciler, Karaköy, Haraççı ve Hacı Ali Sokakları arasında uzanan üçüncü sur: 251.872 arşın kare $\left(141.678 \mathrm{~m}^{2}\right)$,

- Lüleciler ve Tophane arasındaki hendek ve Mumhane, Karaköy ve Yüksek Kaldırım Sokakları boyunca uzanan dördüncü ve son sur: 236.224 arşın kare $\left(132.876 \mathrm{~m}^{2}\right)$,

1864 yılında hâlâ ayakta duran surların toplam uzunluğu en az 3569 m., yıkılmak üzere olan duvarların ortalama kalınlığ 12 , 25 m.'dir. 30 kulenin işgal ettiği bir alan olarak göz önüne alındığında, yıkımlarla bielikte $9.000 \mathrm{~m}^{2}$ 'lik ya da 10 dönümlük bir alan trafiğe açılmış olacaktır (Launay, 1864a).

1. ara sur olarak bahsedilen duvar 1864 yılında tamamen ayakta duran tek ara surdur. $279 \mathrm{~m}$. uzunluğunda olan bu duvar üzerindeki kapılardan ilki Harup Sokağa; ikincisi ise adının da aynı olduğu Azapkapı Sokă̆ı'na açılmaktadır (Launay, 1864a).

2. ara sur Galata Kulesi'nden güneydeki Arap Camii'ne doğru uzanan duvar ile Yanıkkapı Sokağı boyunca ilerleyen duvarın oluşturduğu parça olarak tanımlanmaktadır. Bu duvarlardan 190 m. boyunca birçok özel mülkiyet alanı içinden ve St. Pierre Kilisesi'nin bahçesinden geçerek Yanık Kapı'ya ulaşan sur tamamen ayakta 2 Notice sur les fortifications de Galata 
Resim: 4

Launay'nin haritasina göre ara sur parcalarınin 1864'deki durumu (Genim, 2004, Düzenleme: Esra Okur Coşkunçay)
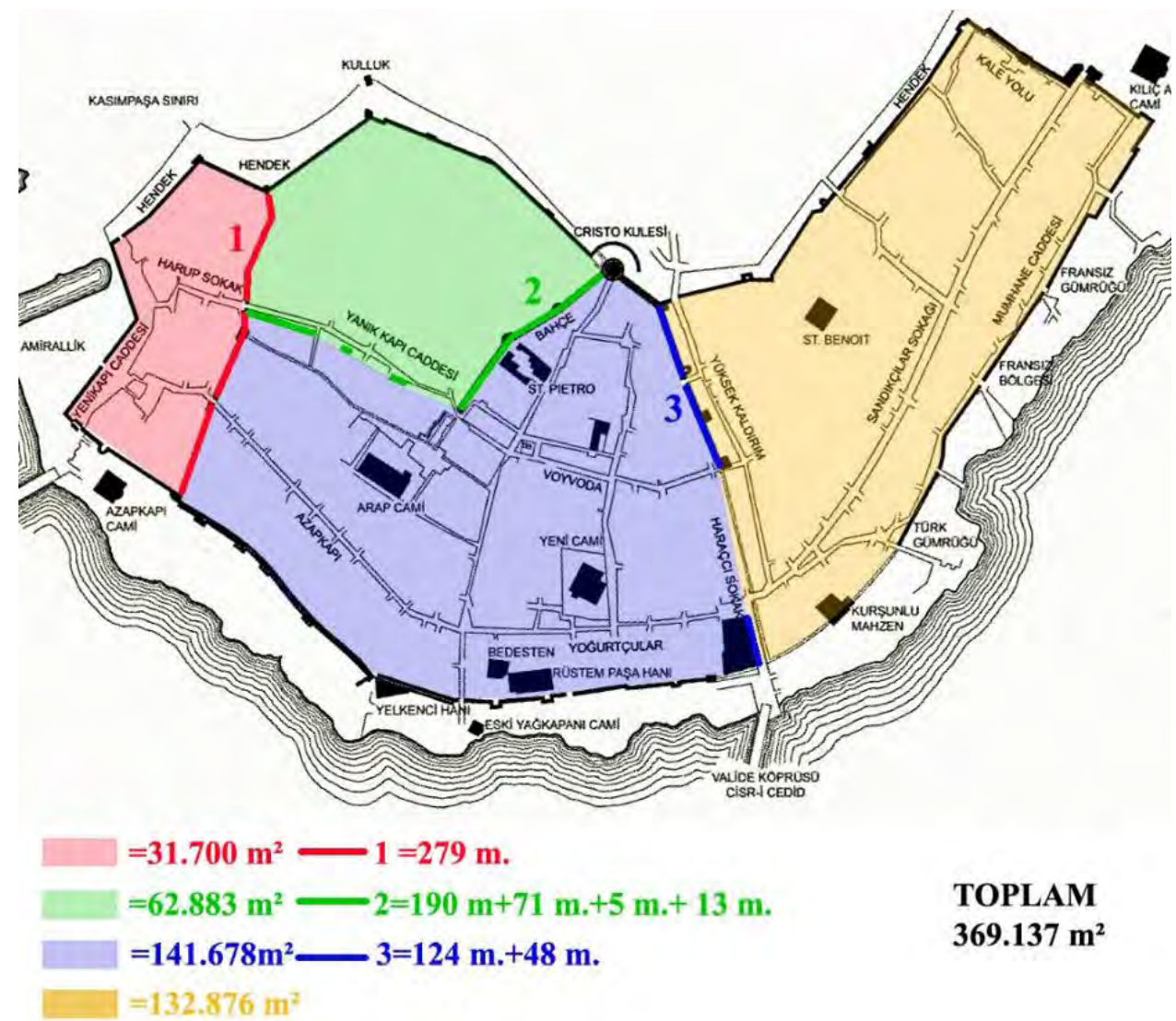

TOPLAM $369.137 \mathrm{~m}^{2}$ kalmıştır. Yanıkkapı Sokağı boyunca devam eden duvar ise $71 \mathrm{~m} ., 5 \mathrm{~m}$.'lik ve 13 m.'lik duvarlar halinde üç parça olarak ayakta kalmıştır. Bu duvarlarla oluşturulan bölgeye Harup Kapısı, Yanıkkapı ve yıkılmış oldukları için görülemeyen Kule ve Kuledibi kapılarından ulaşılmaktadır. Kule Sokak'ta bulunan bir evin bahçesinde bir tarafı yarım daire, diğer üç tarafı ise çokgen şeklinde olan iki kule hâlâ görülmektedir. Bu iki kuleden Dominiken keşişler tarafından sahiplenilen duvar, sürekli bir bakım altında tutularak korunmuştur ve bu yönüyle diğer tüm kulelerden ayrılmaktadır (Launay, 1864a).

3. ara sur ise, Pera ve Yüksek Kaldırım Sokağı'na açılan, yıkılmış olan Galata Kapısı'nın yakınlarındaki alanda, en eski kulelerden biri olup ancak çok iyi durumda olan bu kuleden başlayıp Hacı Ali ve Haraççı sokaklarına doğru uzanan ve Karaköy'de son bulan duvardır. Bu duvar Galata'nın dış surlarını birbirine bağlamaktadır. Yer yer yıkılmadan önce 335 m. uzunluğunda olan bu duvardan Pera'dan Voyvoda Sokă̆ı'na uzanan 163 m.lik parça ile Havyar Han'da 48 m. lik bir parça ayakta kalabilmiştir. 6. Daire'nin kurulmasindan sonra 3. ara sur üzerinde bulunan Karaköy Kapısı, Voyvoda Kapısı ve Horoz Kapı yıkılmıştır. Planlanan Karaköy Hanı inşaatı nedeniyle eni $1.5 \mathrm{~m}$. olan yol trafiği rahatlatmak amacıyla yıkılmıştır. Diğer iki kapı da ulaşımı engelleyen yıkık durumlarından ötürü tehlikeli parçalarından arındırılmıştır (Launay, 1864a) (Resim 4).

2 Aralık 1864 günlü Journal de Constantinople gazetesindeki makalenin devamında Launay, surların yıkılmasıyla yolların artacağını, surlar tarafından kapatılmış olan çıkmaz sokakların açılmasının sağlananacağının üzerinde durmakta, bu sayede sürekli olarak meydana gelen yangınların daha kolay kontrol altına al1nacağını vurgulamaktadır. Uzun zamandır hazırlıkları devam eden araba yolları ile ilgili projelerin de sonunda faaliyete geçeceğini, bunun sayesinde de Galata'daki 
liman bölgesi ile üst mahalleler arasındaki ticari etkinliklerin artacağını düșünmektedir. Ancak bütün bu kazanımlara rağmen yıkımların, Ceneviz surlarının bütünleyici parçaları olan tarihi belgeleri de surlarla beraber ortadan kaldıracağ 1 endişelerini de aktarmaktadır. Ancak 6. Daire Başkanı Server Efendi'nin, surlarda ve kulelerde bulunan tüm yazıt ve tarihi objelerin toplatılmasinı ve bu eserlerin 6. Daire'de arşivlenmesini istemesi konusunda da memnuniyetini dile getirmektedir.

Launay, 5 Aralık 1864 yılında aynı gazetede yayımlanan makalenin son bölümünde tüm surların başlangıç noktası olarak kabul ettiği İsa (Galata) Kulesi'nin yıkımlardan sonra kalan tek ve son kalıntı olacağı bildirilmektedir. Ayrıca kulenin, Galata'da bulunan Harup Kapısı'ndan St. George Kilisesi'ne (Arap Cami) uzanan yapılar dışında, bu grubun en eskisi olduğu vurgulanmaktadir.

Galata surları hakkında yıkılma kararı alındıktan sonra, surlar ile hendeklerin arazilerinin satılması ve el değiştirmesi konusuyla ilgili bazı kararlar alınmıştır. 28.07.1864 (H. 23 Safer 1281) tarihli Şehremaneti'ne gönderilen bir tezkirede, Galata'da kale duvarlarından ve kule kapısı hendekleri arazisinden satılmakta olan mahallere ait senetlerin değiştirilmesi konusunu içermektedir (BOA, A.MKT. MHM., 323, 37). Evkaf-1 Hümayun Nezâreti Celilesi'ne (Saltanat Vakfi Kurumu) yazılan bu tezkirede, Galata'da Büyük Kule Kapısı'nda var olan hendek arazisinden daha öncesinde parça parça satılmış ve sonradan akçeleri verilerek geri alınmış yerler için sahipleri tarafından verilen satış harcının reddi hakkında Nafia Nezaret-i Celilesi'nden (Bayındırlı Bakanlı̆gl) Şehremenati'ne gönderilen tezkirenin ekte yer aldığı belirtilmiş, ancak dosyada bu belge yer almamaktadır. 13.08.1864 (H. 10 Rabiu'l-evvel 1281) tarihli aynı konuyu içeren diğer bir belgede yine aynı husus belirtilmiş, ancak ekte yine bahsedilen belge bulunmamaktadır (BOA, A.MKT. MHM., 309, 4). Konuyla ilgili 02.10.1864 (H. 1 Cemaziye'l-evvel 1281) tarihli bir başka dosyada ise Valide Sultan Vakfı'na kayıtlı
Galata'daki kale duvarları ve kale kapısı hendekleri arazisinden satılmakta olan yerler için gerekli mülknamenin düzenlenmesi konusu yer almaktadir (BOA, A.MKT. MHM., 313, 61). Maliye Nezaret-i Celilesi'ne (Maliye Bakanliğl) gönderilen bu tezkirede bahsedilen araziden satılmakta olan yerler için gereken oranın mülk olarak verildiğine dair belgenin hazırlanmasının ve acele olarak yazdırılarak Bâbıali'ye gönderilmesinin gerektiği ifade edilmiştir. 07.12.1864 (H. 8 Receb 1281) tarihli Sadaret'e gönderilen bir dosyada aynı araziden ayr1lan bölgelerin Saltanat-1 Seniyye Vakfi'na ait olacağı konu başlığı yer almaktadır (BOA, İ.DH., 531, 36789). Ayr1lan bu arazinin 24.600 arşın olduğu, bu yerlerden elde edilecek gelirle 6. Daire Belediyesinin borçlarının karşılanacağı ve belediyenin süsleneceği belirtilmiştir. Elde edilecek gelirle ileride meydana gelebilecek satış ve devir harçları ile mirasının vakfa ait olacağı, bu bölge için yazılan mülknâme-i hümayunun Maliye Nezaret-i Celilesi'nin tezkiresiyle beraber Sadaret'e sunulduğu ifade edilmiştir.

Galata'daki Kule-i Zemin arazisine dair 19.12.1865 (H. 30 Receb 1282) tarihli bir dosyada Meclis-i Vala'nın aldığı bir kararın uygulanması için Sadaret'e danışılmıştır (BOA, I.MVL., 544, 24459). Meclis-i Vala, Galata'da bulunan Kule-i Zemin arazisinde komisyon tarafından isteklilerine satılmış olan araziden Kılıç Ali Paşa Caddesi'nde yer alan 24 arşınlık (20 m.) sur bölümünün, Kireçkapısı Gümrüğü ve Galata Gümrüğü ambarının arka duvarı sayılan kale duvarından $5 \operatorname{arşın~}(4 \mathrm{~m}$.) mahallin Galata Gümrüğü ambarı için satın alınmaları konusunun önemli ve lüzumlu olduğunu Rüsumat Emaneti’nin (Gümrük Iddaresi) 22.11.1865 (H. 3 Receb 1282) tarihinde kendilerine yolladıkları bir yazı üzerine öğrendiklerini dile getirmişlerdir. Ancak bu araziyi Kadinko nam hatun ile Bahçıvan oğlu Avadis'in 27.500 kuruşla satın alınması anlaşmasının kararlaştırıldığı belirtilmiştir. Ancak bahsedilen yerlerin gümrükler binalarına bitişik ve ilişkili olduğu, daha önce verilen bir emirle gümrük için gerekli olup olmadığı komisyonca anlaşıldıktan sonra taliplerine 
satılması gerektiği halde nasıl olduğu bilinmeyen bir durumla buraların 13.000 kuruş peşinatla adı geçen kişilere satılmış olduğu ifade edilmiștir. Bu arazilerin satın alınmasının gerekliliği belirtilmiş, bu ișlem için de şu anki mülk sahiplerine mevkisine göre uygun bir fiyat olan 27.500 kuruşun ödenmesi için gerekli ücretin Rüsümat Emaneti'ne gönderilmesi için izin istenmiştir.

Galata surlarının yıkım kararı alınmasından sonra sur yıkımları sırasında tehlike yaratan bazı durumların ortaya çıkabileceği ilgili makamlara gönderilen dilekçelerden öğrenilmektedir. Bunlardan bir tanesi Fransız Sefareti tarafından Makam-1 Nezaret-i Celile-i Hariciye'ye (Dış İsleri Bakanliğl) 02.09.1876 (H. 13 Muharrem 1293) tarihinde gönderilen “Galata'da Perşembe Pazarı'nda bulunan kale duvarlarının y1kılmasından bazı sakınca ortaya çıkacağı nedeniyle gerekli raporun düzenlenmesine bağlı olarak tatil ettirilmesine dair" başlıklı müzakeredir (BOA, HR.TO., 204, 64). Bu müzakerede Galata'da Perşembe Pazarı'nda yer alan surlar ile kulenin Belediye tarafından yıktırılarak açık arttırmaya konulacağı haberi alındıktan sonra bu konuda bazı görüşleri açıklamak istemişlerdir. Dominiken rahiplerinin elçilik adına kullanmakta olduğu Dominiken Manastırı'nın, eskiden beri bu duvarlara dayandığı, bu duvarların emlakin duvar parçaları olduğu, kullanım hakkının da asırlardan beri adı geçenlere ait olduğu bildirilmiştir. Ancak, bu kulenin yıkılması ve bu manastırın dayandığı surların açık arttırmayla satılması durumunda Dominiken cemaatinin zarar göreceği ifade edilmiştir. Bu sur ve kulenin, kullanıcıların binalarına yıkılması tehlikesinin olup olmadı ğının mimarlar tarafından kontrol ettirilip gereken rapor elde edilinceye kadar, bahsedilen önlemlerin ve ilan olunan açık arttırmanın geciktirilmesi hususunda Belediye'ye talimat verilmesi istenmiştir.

\subsection{Galata Surları Hakkında Koruma Karart Alınmast}

Sur yıkım kararı ve çalışmaları başladıktan yaklaşık otuz yıl sonra, Osmanlı
İmparatorluğu yönetimi, İstanbul ve Galata surlarının asar-1 attika (eski eser) olarak değerlendirmeye başlamıştır. Surların eski eser olmalarının yanında kentin korunması için de gerekli olduğu ifade edilerek, yıkılmak üzere olanların y1kılması ve sağlam olan parçalarının korunması gerektiğiyle ilgili bir takım yazışmalar yapılmıştır.

Bu yazışmalardan Osmanlı Arşivi'nde incelenen ilk dosya, Dâhiliye Mektubi Kalemi'nin (İç Issleri Makamı) SadaretPenâhî’ye (Başbakanlı̆a) 10.04.1892 (H. 12 Ramazan 1309) tarihinde gönderilen, Galata ve İstanbul surlarının tarihi eser olması yüzünden bunların muhafazası için yıkılmaya yüz tutmuş ve harap yerlerin yıkılması konusunu içeren dosyadır (BOA, DH.MKT., 1940, 18). Bu dosyadaki belgede, Galata ve İstanbul surlarının zabita ve koruma amaçlı gerekliliğinin yanında eski eser sayılması nedeniyle Kule-i Zemin Komisyonu'nca yıkılmasından ve satılmasından vazgeçilerek ihtiyaç anında onarılarak eski hallerinde korunması emrinin padişah tarafından daha önceden verilen bir iradede yer aldığ bildirilmiştir Şimdiye kadar bu uygulamaya özen gösterildiğini, ancak büyük bir kısmı oldukça harap olmuş ve yıkılmaya yüz tutmuş olan kale duvarlarının bu hallerinin bir fayda sağlamadığ 1 , yine de eski eser olmaları nedeniyle eski haline çevrilerek korunmasının oldukça masraflı olduğu ifade edilmiştir. Eski eserlerden olan bu sur duvarlarının tamamen kaldırılmasının padişah emrine muhalif olduğu ve caiz olmadığı, ancak harap ve yıkılmaya yüz tutmuş olan yerlerin onarımı için de bütçenin yetersiz olduğu düşünülmüştür. Böylece bu tür yerlerin y1kılarak ortadan kaldırılması için izin istenmiștir.

12.05.1892 (H. 14 Sevval 1309) tarihinde ise konuyla ilgili tezkire, Dâhiliye Mektubi Kalemi'den (İç İşleri Bakanlığı Yazı İşleri) Şehremaneti'ne gönderilmiş; bu tezkirede, sağlam kalan parçaların korunması, tehlikeli ve sakıncalı olan ve yıkılmaya yüz tutmuş olanların yıkılması düşüncesi ile öncelikle bu harap ve yıkılıp mahvolmuş veya mahalle şekline girmiş olan mahal-

Sayl 25, Mayis 2018 
lerin araştırılarak bildirilmesi istenmiştir (BOA, DH.MKT., 1947, 112).

Galata surlarının durumlarının öğrenilmesi ve ona göre hareket edilmesi için araştırma yapılması istendikten sonra Galata ve İstanbul surlarından harap olmuş ve yıkılan mahallerin ufak bir krokisi tanzim edilmesi konusunda 14.10 .1892 (H. 22 Rabiu'l-evvel 1310) tarihli dosyada bir takım yazışmalar yapılmıştır (BOA, $B E O$, 88, 6554). Bu yazışmaları içeren dosyada yer alan bir belgede, Şehremaneti'nden Dahiliye Nezaret-i Celilesi'ne ( $\dot{I}_{\zeta} \dot{I}_{S}$ leri Bakanliğl) surların durumunun araştırılıp bildirilmesi ileri sürülen bildirim üzerine adı geçen bölgelerin büyüklüklerine dair Kule-i Zemin Komisyonu'ndan alınan defterin sunulduğu belirtilmiştir. Bazı mülk sahiplerince zamanında bu sur bölgelerinden izinsiz olarak kendi mülklerine ilave ettikleri yerlerin de bu deftere işlendiğinden bahsedilmiştir. Ayrıca bu yerlerin devir işlemleri ve ayrılmaları için resmi belgelerin komisyona gönderildiği, mahvolan yerlerin peşinatlarının gerekli görülenlerden alınması konusunun komisyon tarafından bildirildiği ifade edilmiştir. Gerekli iznin verilmesi için Şehremini (Belediye Başkanı), Dâhiliye Nezareti'nden izin istemiştir. Dosyadaki diğer belgede Sadaret'in, Şehremaneti'nden gönderilen defterde isimleri geçen sur bölgelerinin ufak bir krokisinin çıkarılarak defterle birlikte tekrar gönderilmesi konusundaki tezkiresi yer almaktadır.

Sadaret-Penâhî'den verilen tezkire üzerine 21.10.1892 (H. 29 Rabiu'l-evvel 1310) tarihinde Dâhiliye Nezaret-i Celilesi (İ̧̧ İsleri Bakanlığl) Şehramenti'ne durumu bildirerek hazırlanan defteri iade etmiş, buraların krokilerinin çıkarılarak düzenlenmesini, bir önceki deftere krokilerin de eklenerek acele olarak gönderilmesini istemiştir (BOA, DH.MKT., 2013, 47).

Dâhiliye Mektubi Kalemi'nin (iç İşleri Bakanlığı Yazı İsleri) Sadaret'e 17.12.1892 (H. 27 Cemaziye'l-evvel 1310) tarihinde gönderdiği, emlak tecavüzüne mani olmak için Galata ile İstanbul surlarının harita ve krokisinin çıkarılması konusundaki yazısında (BOA, DH.MKT., 2031, 53) bazı mülk sahipleri tarafından izinsiz olarak kendi yapılarına ekledikleri bazı sur bölgelerinin ufak bir krokisinin çıkarılması hususundaki emrin Şehremaneti'ne iletildiğini belirtilmiştir. Ancak Şehremaneti tarafından zamanında bu bölgelerin haritalarının düzenlenmediğinin, yeni bir kroki hazırlamak için hava şartlarının uygun olmadığının, bu işin oldukça masraflı ve zaman alan bir çalışma olacağının kendilerine iletildiğ $i$ bildirilmiştir. Bu yüzden boşu boşuna masraf yapmamak ve zaman kaybetmemek için defterdeki daha önce sunulan bilgilerin yeterli görülmesi Şehremaneti tarafindan arz edilmiştir.

Kroki hazırlanması konusunda verilen emirlerin Şehremaneti tarafından yapılamayacağının bildirilmesi, sadece İstanbul ve Galata Surları üzerinde yaptığı araştırmaları içeren defteri sunmaları üzerine Babıâli 20.12.1892 (H. 30 Cemaziye'l-evvel 1310) tarihinde Dâhiliye Nezareti'ne bu konuda son sözü kendilerinin söyleyebileceğini içeren sert bir yazı gönderilmiştir (BOA, BEO, 126, 9382). Krokinin hazırlanması için yeteri kadar görevli mühendisin olduğu, bu işin yapılmasının masraflı olacağı iddialarının geçerli olmadığı belirtilerek, eski bildirim için gerekenin yapılması konusunda tekrar emir verilmiştir. Dâhiliye Nezareti de 31.12.1892 (H. 11 Cemaziye'l-ahir 1310) tarihinde Babıâli'den alınan emirleri Şehremaneti'ne iletmiştir. Şehremaneti'nin araştırmalarını Sadaret'e sunmuş olduğu defterde ise komisyon tarafından satılan, mahalle şekline giren, Şimendifer İdaresi'ne terk edilen yerler ile bazı kimseler tarafindan izinsiz olarak emlaklerine eklenip kullanılmakta olan bölgelerin yer ve ölçüsünün bildirildiği belirtilmiştir. İstanbul surları ile ilgili daha fazla maddenin yer aldığ Galata surları ile ilgili sadece bir maddeye yer verilmiştir. Bu maddede Galata bölgesinde yer alan kale duvarıyla hendek arazisinin komisyon tarafından tamamen satıldığı; yalnızca Kürkçü Kapısı ile Yemeniciler Caddesi tarafinda iki emlak arasında bir miktar sur parçasının harap durumda bulunduğu belirtilmiştir.

Sadaret'in yinelenen emrinin 
Şehremaneti'ne yeniden iletilmesinin ardından, Dahiliye Nezareti'ne konuyla ilgili Şehremaneti'nden yeni bir tezkire gönderilmiştir. Bu tezkirenin içeriği 08.04.1893 (H. 21 Ramazan 1310) tarihli dosyada yer almaktadır (BOA, DH.MKT., 1, 77). Şehremaneti'nden alınan cevap sonrasinda Dahiliye Nezareti'nin Sadaret'e gönderdiği yazısında, belediyede görev yapan mühendislerin bahsedilen krokinin çıkarılması için yeterli sayıda olmadığının, diğer dairelerden işin yapılabilmesi için mühendis getirildiğinin ancak yine de bu işin yapılmasının imkanlar dışında bulunduğunun Şehremaneti tarafindan iletildiği bildirilmiştir. Sadaret aldığa bu bilgi üzerine Dahiliye Nezareti'ne, krokinin çıkarılmasının önemli ve gerekli olduğunu, mevcut mühendislerin bu işi yapamayacak olmaları durumunda dışarıdan ücretleri ödenerek yeteri sayıda mühendisin getirtilmesinin sakıncalı olmadığını ve gerekiyorsa getirtilmesini iletmiştir. Dahiliye Nezareti de bir tezkire ile Sadaret'in emirlerini Şehremaneti'ne göndermiştir.

Sadaret, Dahiliye Nezareti ve Şehremaneti arasında yapılan Galata surlarının eski eser olarak nitelendirip yıkımlardan vazgeçilmesi ve bölgenin krokisinin çıkarılması konusuyla ile ilgili yapılan bu yazışmalardan Osmanlı yönetiminin surlara tarihi eser olarak yaklaşımları açıkça görülmektedir. Ancak bölgeyle ilgili çıkarılması emredilen haritaya Osmanlı Arşivi'nde rastlanmamıştır.

19. yy'ın ikinci yarısında Osmanlı İmparatorluğu'nda eski eserlerin korunmasına yönelik ilk çalışmalar ve düzenlemeler yapılmaya başlanmıştır. 1858 tarihli Ceza Kanunu'nun 133. maddesi taşınmaz eski eserlerle ilgili ilk düzenlemedir ve bu düzenlemede bu tür eserlerin yıkılmas1, tahrip edilmesinin yasak olduğu bildirilmektedir. 1869 tarihli Asar-1 Atika Nizamnamesi'nin taşınmazlarla ilgili tek hükmünde, toprak üstündeki eserlerin tahrip edilemeyeceği söylenerek kazı izninin yalnız toprak altındaki eserler için geçerli olduğu vurgulanmaktadır (Çal, 2005). 1874 tarihli II. Asar-1 Atika Nizamnamesi’nde eski eserin tanımı yapılmış ve eski eserlere Türk-İslam çağı öncesi olma kriteri getirilmiştir ve taşınmazların korunması için bir takım kurallar belirlenmiştir. 1884 yılında yayınlanan III. Asar-1 Atika Nizamnamesi'nde ise taşınmazların korunması için daha detaylı tedbirler getirilmiştir.

\section{Cumhuriyet Döneminde Galata Surlart}

Cumhuriyetin ilanınından itibaren Ankara'nın başkent olarak seçilmesinin ardından kentte yoğun imar faaliyetlerine geçilmiştir. Yeni kurulan ülkenin modern başkentini oluşturmak hedeflenmişti. İstanbul ülkenin zaten batıyla en içiçe olan, en batılılaşmış kentiydi. İstanbul'un Cumhuriyet sonrası ilk büyük ölçekli kentsel planlama çalışması ise 1937 yılında Henri Prost'un tamamladığ 1 "İstanbul Avrupa Ciheti Nazım Planı"dır. Prost, 1939-1948 arasinda "Anadolu Ciheti Nazım Planı” ile Boğaziçi’nin her iki kıyısındaki yerleşimlerin planları üzerinde çalışmıştır. Şehirci, Galata ve Beyoğlu'ndaki tarihi mahallelerde yapı yoğunluğunu çok yüksek bulmuş, dar sokak ve avlulara güneş ışığının giremediği bu alanın sağlıklılaştırılması gerektiğini savunmuştur. Bu bölge için ekibiyle birlikte geliştirdiği sektör planlarında kent dokusunun kademeli olarak bütünüyle yenilenmesini öngörmüştür (Bilsel, 2011).

\subsection{Menderes Yıkımları}

Cumhuriyet sonrasında İstanbul'da beraberinde kamulaştırmaları da getiren büyük ölçekli imar hareketi 1950 - 1960 yılları arasında Adnan Menderes'in başkanlığını yaptığı Demokrat Parti iktidarı ile gündeme gelmiştir.

Kuban (2004), 2. Dünya Savaşı sonrasında Amerikan imgelerinin üstün bir statü niteliği kazandığını, Menderes'in kapsamlı bir kalkınma programı hazırlayarak imara duyduğu kişisel ilgiyle İstanbul'un gelecekteki gelişmesi üzerinde önemli etkisi olduğunu belirtmektedir. Demokrat Parti iktidarı sırasında Menderes'in doğrudan kontrol ettiği 4 yıllık imar çalışmaları sırasında denizin doldurulmasıyla oluşturulan 

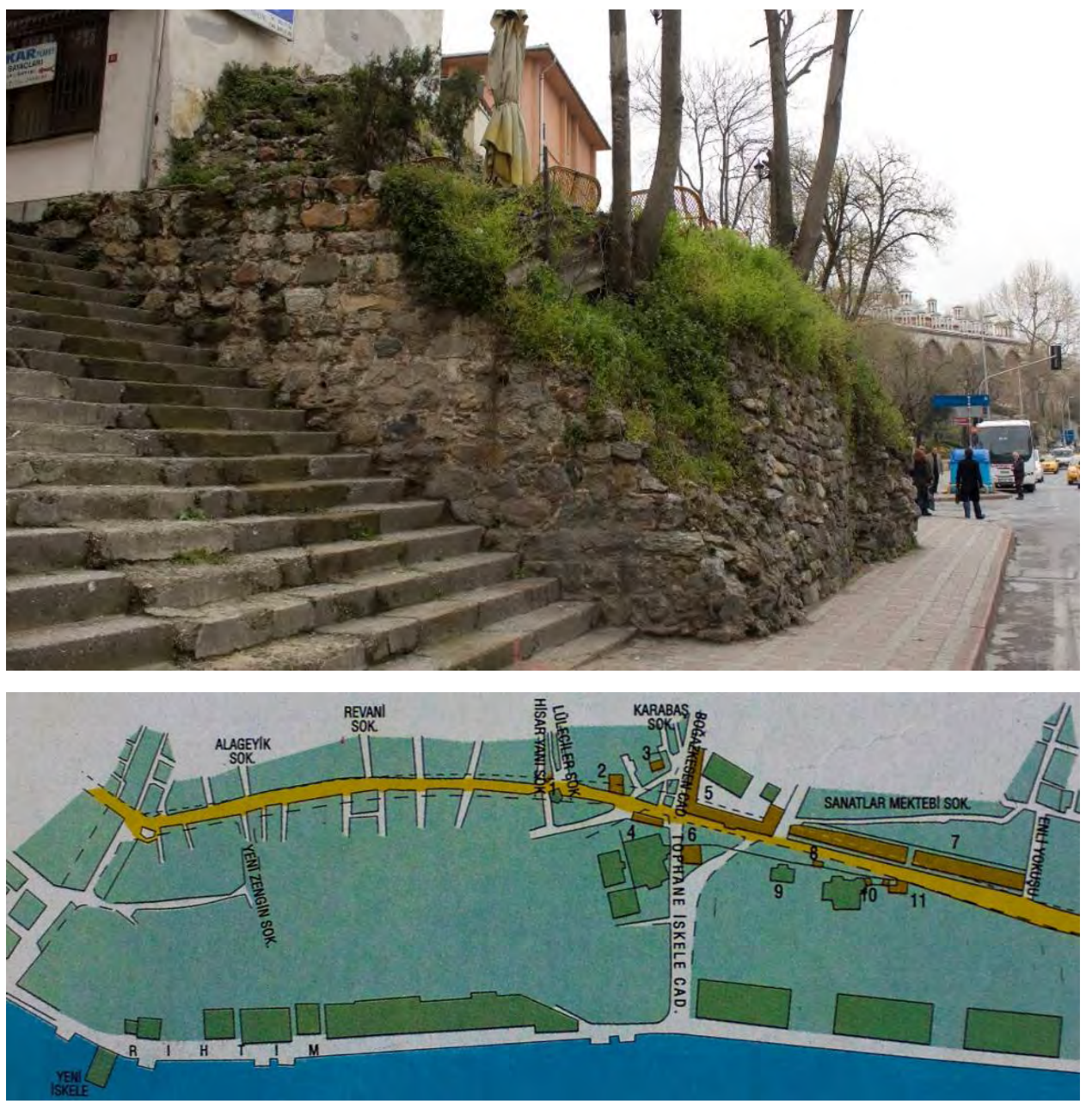

sahil bulvarları, tarihi yarımadada ve civarında açılan bulvarlar, yol genişletme çalışmaları, meydan düzenlemeleri, liman tesisleri açılması gibi imar hareketleriyle kent plansız bir biçimde keyfi uygulamalar görmüştür.

Menderes istimlâkleri olarak adlandırılan bu imar hareketleri ile tarihi sur içi bölgesinde $60 \mathrm{~m}$. genişliğinde bulvarlar açılmış, kara surlarının bir kısmı bu yolların yapılması için yıkılmış, sahili doldurarak açılan yollar ile deniz surları kara tarafında kalmış, yapı aralarında kalan Haliç surları saptaması bile yapılmadan yıkılmış, bazı tarihi yapılar ile tarihi kent dokusu yok edilmiştir (Çeçener, 1994). Yolların kotları indirilerek ya da kaldır1larak büyük anıtların bazılarının temelleri havada kalmış, bazıları ise toprağa gömülmüştür (Kuban, 1994).
Galata da kentteki bu yoğun imar çalışmalarından etkilenmiştir; bölgenin eski sivil mimari örnekleri yok edilmiş, Galata surları içinde Kemeraltı'nda yeni bir cadde açılmış, Kemeraltı Caddesi genişletilmiş, bölgeye uygun olmayan niteliksiz, yoğun ve yüksek yapılaşmaya izin verilmiştir (Çeçener, 1994).

Galata surları içinde Kemeraltı Caddesi'nde 1445 tarihli kitabeye sahip olan bir burç tahribata uğramıştır. Bugün Hisar Sokak ile caddenin köşesinde yer alan burç temel seviyesine kadar düşürülmüştür (Ünsal, 1969) (Resim 5 -Resim 6).

\subsection{Haliç Metro Geçiş Köprüsü Projesi}

Taksim - Haciosman arasında yapılan M2 metro hattının Yenikapı'ya kadar uzatılacak hattı için 2000'lerin sonuna doğru Haliç üzerinde bir metro geçiş köprüsü yapılması gündeme gelmiştir. Hazırlanan
Resim: 5

Kemeraltı caddesinde istimlakler sirasinda tahrip olan burç (Okur Coşkunçay, 20II)
Resim: 6

Tophane'de Menderes dönemi istimlakleri (2 numara:tahrip edilen burç) (f̧eçener, 1994) 
Resim: 7

Emekyemez ve Arap Camii Mahallelerinde Istanbul Metrosu Haliç Metro Geçis Köprüsü Projesi için istimlak sonrası açı̆̆a f̧ıkan sur duvarları vaziyet planı (BIMTAS, 20II, Düzenleme: Esra Okur Coşkunçay)

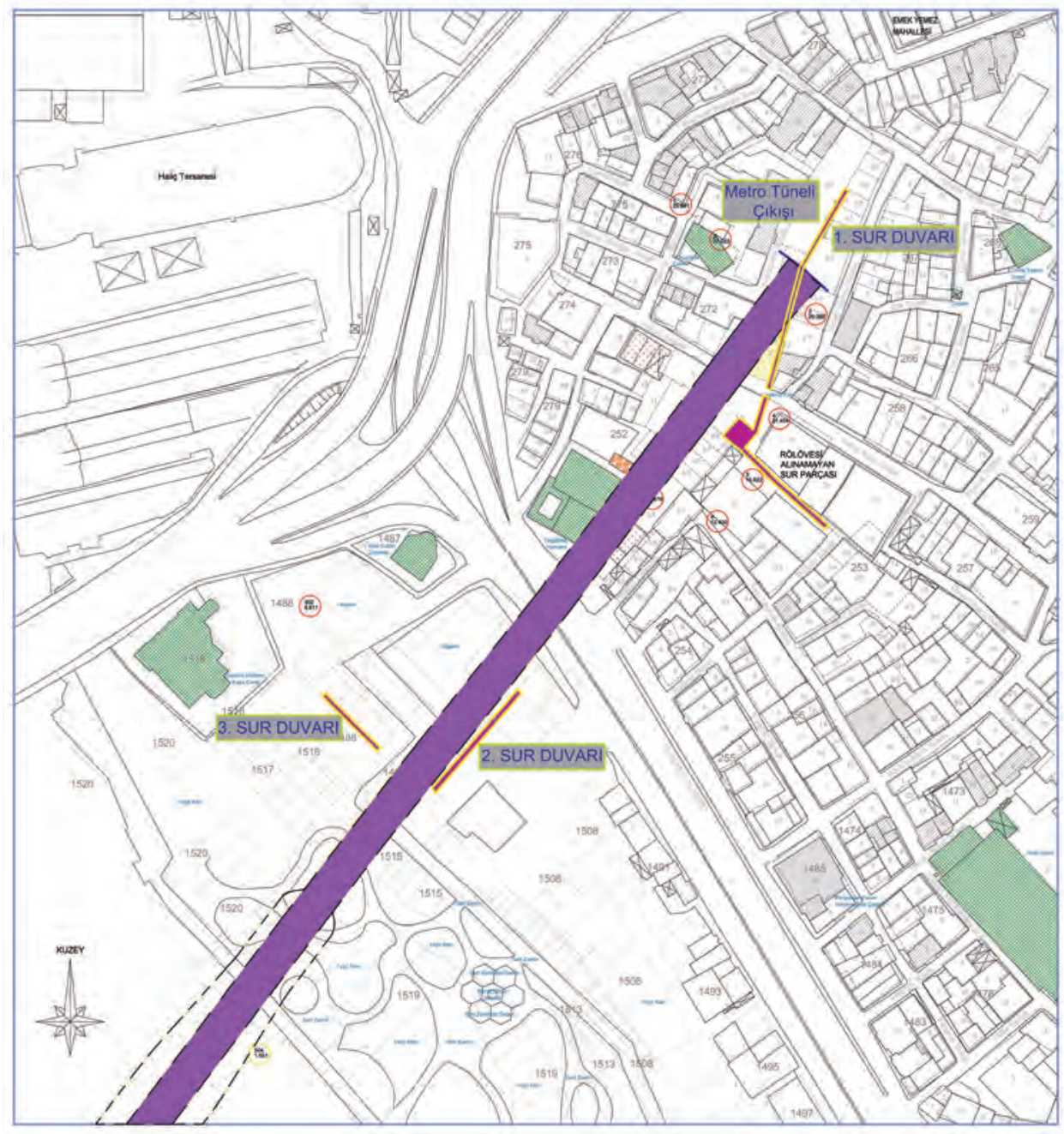

Resim: 8

Emekyemez ve Arap Camii Mahallelerinde

Istanbul Metrosu Haliç Metro Geçiş Köprüsü Projesi için istimlak sonrası af̧ı̆̆a f̧ıkan sur duvarları rölövesi (BIMTAş, 20II)

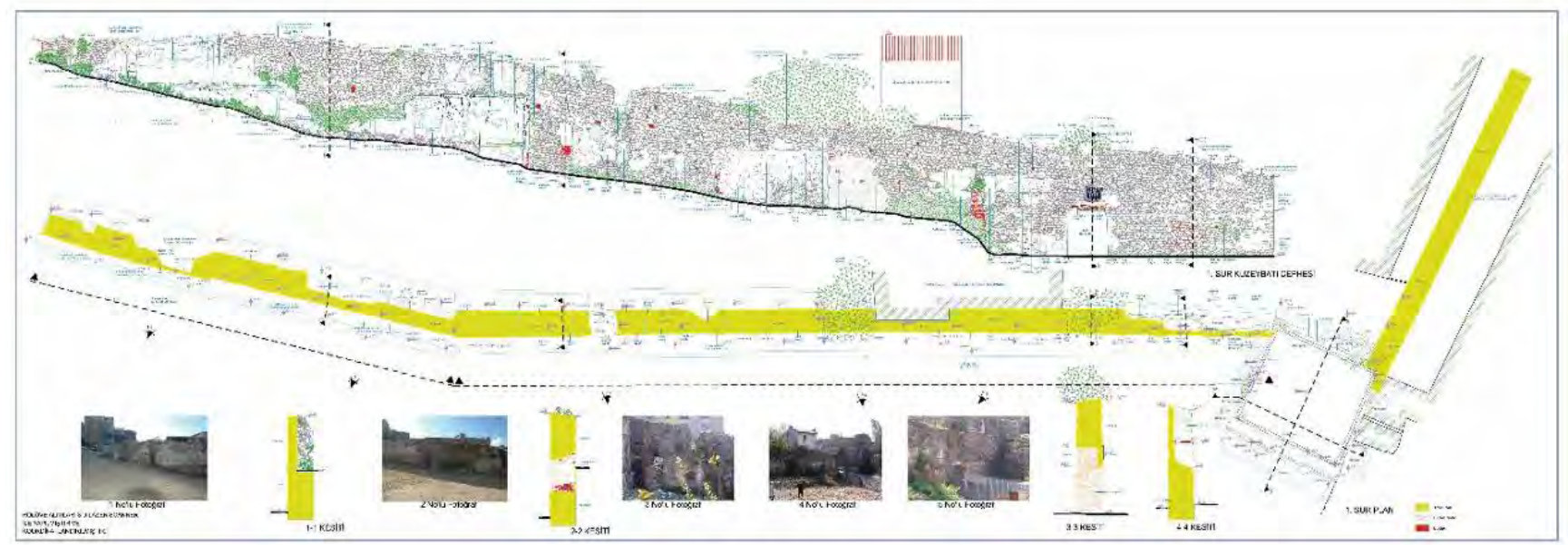



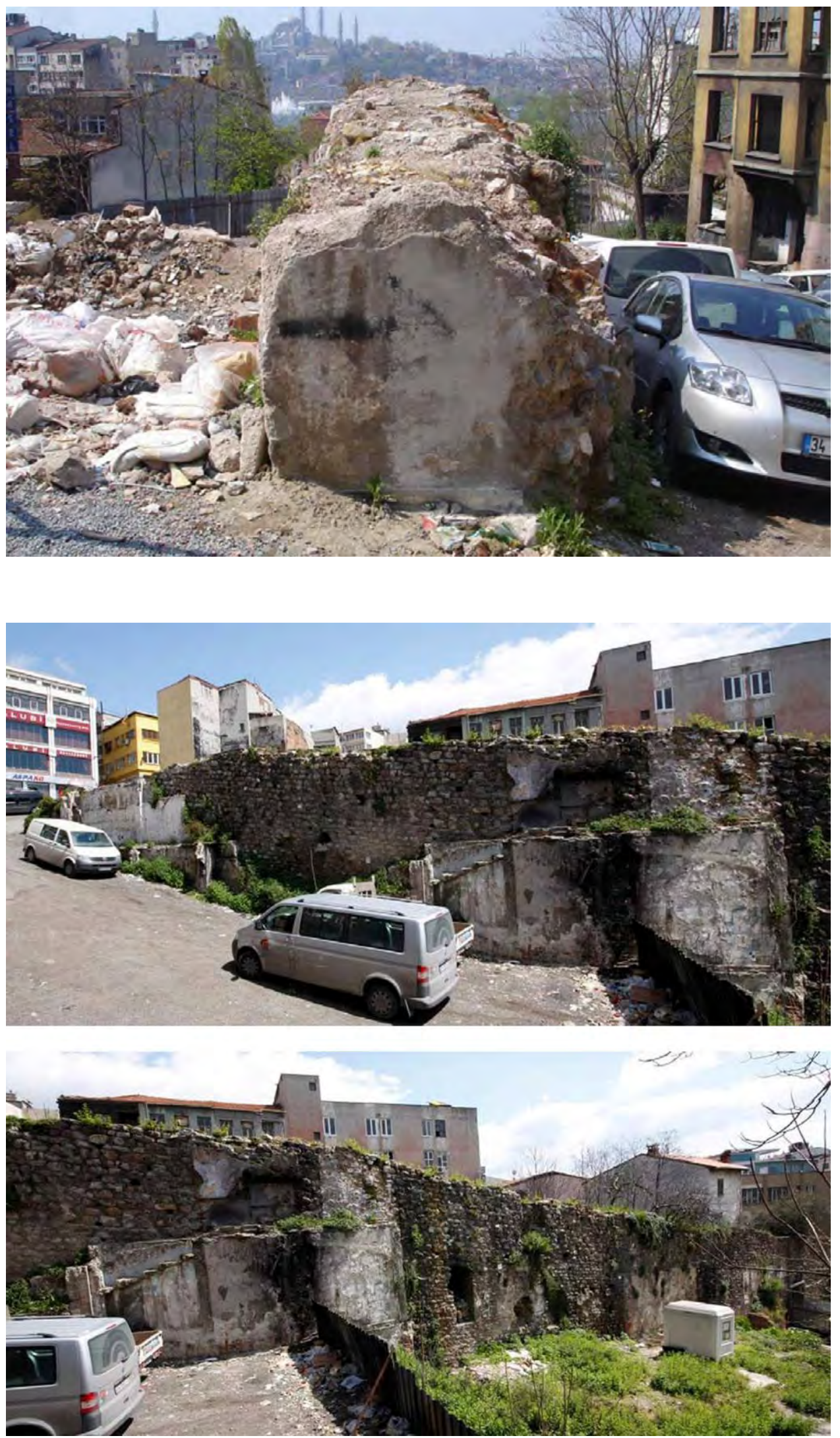

Resim: 9

istimlak sonrası ortaya f̧ıkan ve metro hattı

üzerinde kalan surlar (BIMTAS, 2009).
Resim: 10

istimlak sonrası ortaya çıan ve metro hatt üzerinde kalan surlar (Okur Coşkunçay, 20II) 
Resim: "I

surları delip geçen metro tüneli (URL I)

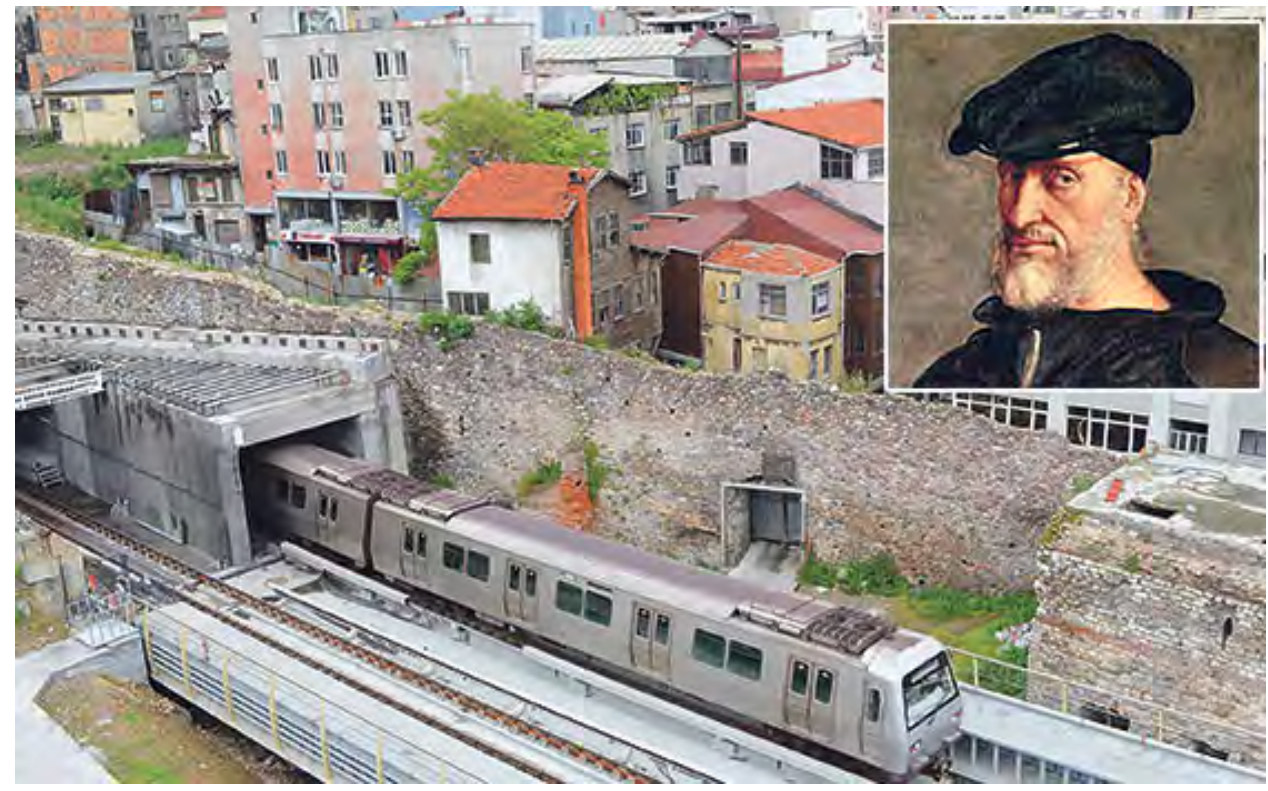

projelerde Taksim'den Şişhane'ye bağlanan metro tüneli, Galata'da bulunan Emekyemez ve Arap Camii mahallelerinde bulunan Galata surları ile bazı tarihi ve tescilli yapıların bulundukları bölgeden yer üstüne çıkarak, Haliç’te yapılacak köprü ile tarihi yarımadada Süleymaniye bölgesinde tekrar yer altına girecektir.

"İstanbul Metrosu Haliç Metro Geçiş Köprüsü Projesi” kapsamında Emekyemez ve Arap Camii Mahallelerinde, yeni yap1lacak metro köprüsü ile metro tünel çıkışı arasında yer alan parsellerdeki yapılar istimlak edilerek yıkılmıştır. Bu yıkımlar sonucu ortaya $150 \mathrm{~m}$. uzunluğundaki sur hattı ile bu hat üzerinde bulunan kule ile kapı, $44 \mathrm{~m}$. uzunluğundaki kemer dizili sur duvar1 ve $28 \mathrm{~m}$. uzunluğundaki kitabeli sur duvarı ortaya çıkmıştır (Resim 7).

İstanbul II Numaralı Kültür ve Tabiat Varlıklarını Koruma Bölge Müdürlüğü tarafindan hazırlanan 12.02.2010 tarihli "İstanbul Metrosu Haliç Metro Geçiş Köprüsü Projesi” kurul kararları özetleri sunumunda metro güzergahına rastlayan sur bölümlerinin başka bir yere taşınarak yeniden inşa edilmesi gündeme geldiği belirtilmiştir. Bu çalışmada surları taşıma kararından daha sonra vazgeçildiği aktarılmış, sadece metro tüneli çıkış noktasında sur hattına rastlayan kısım ve tüm surlar için bir restorasyon projesi hazırlanması ve bu projeye göre uygulama yapılması kararı alındığ 1 dile getirilmiştir.

Ancak surlarla ilgili restorasyon çalışmaları henüz bitmeden M2 metro hattının uzantıs1 olan Yenikapı - Şişhane metrosu, istimlak edilen alanda ortaya çıkarılan sur duvarını tahrip ederek 2014 yılında faaliyete başlamıştır. Yenikapı'da yer altında başlayan metro tüneli Süleymaniye'de yeryüzüne çıarak Haliç’i köprü üzerinde geçerek devam etmekte, Galata'da Emekyemez ve Arap Camii mahallelerinde ayakta kalan en uzun sur parçasının kuzey bölümünü tahrip ederek yer altına girmektedir (Resim 7). Yaklaşık on yıl boyunca metro güzergahında bulunan surların koruma kurulu tarafindan rölöve, restitüsyon ve restorasyon projelerinin yapılması yönünde çeşitli yazışmalar ve istimlak sonrası bahsedilen surların rölöveleri yapılmıştır (Resm 8). kapanıp açılarak aktif olarak kullanılan, Galata bölgesinin kimliğinde önemli bir yere sahip olan ve yapılışı Cenevizliler'e dayanan, yüzlerce yıllık geçmişi olan surlardan kalan bu son önemli parçalar bir koruma önlemi alınmadan hasar görmüştür. İstimlak sonrası ortaya çıkartılan diğer sur parçaları da şu an bakımsız ve atil bir şekilde bırakılmış olup adeta yıkılması beklenmektedir ve surların geleceğiyle ilgili herhangi bir gelişme mevcut değildir. Ancak 19. yüzyıla kadar hala kapıları 


\section{Sonuç}

Galata bölgesi Konstantiopolis kentinden ayrı bir yerleşim yeri olarak Haliç'in diğer tarafında kentin hemen karşısında kurulmuştur. 1. Konstantin tarafından antik çağda Sykai olarak adlandırılan bölgede, sinırları tam olarak bilinmeyen surlar yapılmış; 2 . Theodosius zamanında bölge 13. Regio olarak Konstantiopolis'e bağlanmıştır. Iustinianus döneminde ise daha önceden yapılan surlar yenilenmiştir. Cenevizlilerin 1303 yılında Galata'da sahip oldukları ilk imtiyaz bölgesinin sınırları belirlendikten sonra, sur yapımı altı aşamada tamamlanmış ve 15. yüzyılda son şeklini almıştır. İstanbul'un Osmanlı İmparatorluğu tarafından fethiyle, Galata surları Fatih Sultan Mehmet tarafindan sembolik olarak bir miktar alçaltılmış, ancak bütün olarak yıkılmamıştır.

Ortaçağda savunma anlayışıyla yapılan Galata surları, geç Osmanlı dönemlerinde bölgenin nüfusunun artmasıyla işlevi kalmamasına rağmen sıkışık kent dokusu içinde yapı aralarında olsa da ayakta durmaktadır. Başbakanlık Osmanlı Arşivi'nde bulunan belgelerde Galata surlarının yıkım süreci üç bölümde izlenebilmektedir.

İlk süreçte, işlevsiz kalan, deprem ve yangınlar yüzünden hasar gören sur duvarları ve kapıları, hasarlı durumdayken yarattıkları tehlike ve oluşturdukları engel sebebiyle onarımlar geçirmiştir. Farklı sebeplerle tahrip olan kapıların yeniden yapılma durumları da zaman zaman gündeme gelmiştir. Onarımlarının yapılması konusunda en çok gündeme gelen kapıların sahil şeridinde yer alan kapılar olduğu ortaya çıkarılmıştır. Arşiv belgelerinde gözlenen bu ilk aşamada, kapıların geceleri kapatılıp gündüzleri açıldıkları ve kapılarda nöbetçi bulundurulması dikkat çeken başka bir noktadır.

Diğer bir süreçte, Tanzimat sonras 1 batılılaşma hareketleriyle İstanbul ilk belediye örgütüne sahip olmuş; Galata bölgesi de 6 . Belediye Dairesi'ne bağlanmıştır. 1863 tarihinde surların çoğunun yapılar arasında sıkıştı̆̆ 1 görülmüş, yer yer de işe yaramaz bir halde kalmaları yüzünden yıkılmaları istenmiştir. Diğer gerekçeler olarak da trafiği rahatlatmak, işlevsiz kalan surların ve hendeklerinin arazilerinin satılarak Avrupa'da yer alan apartmanlar gibi modern yapılar yapmak, gayrimüslim ve levantenlerin oturduğu bu bölgeyi Avrupa'daki kentlerin görüntüsüne kavuşturmak gösterilmektedir. 6 . Daire mühendisi olan Marie de Launay, surlarla ilgili bir çalışma ve harita hazırlamak üzere görevlendirilmiş; 1864 yilında da Journal de Constantinople gazetesinde Galata surlarıla ilgili bir yazı dizisi hazırlamıştır. Başbakanlık Osmanlı Arşivi'nde incelenen belgelerde surlarla ilgili olan son süreçte ise, surların yıkım kararının alınmasından yaklaşık 30 yıl sonra Galata ve İstanbul surlarının tarihi eser oldukları kabul edilmiş; çok hasarlı ve neredeyse yıkılacak durumda olan sur duvarlarının yıkılmalarına, sadece iyi durumda olanların korunmasına karar verilmiştir. Bu yıkım işlemlerinin yapılmasından önce bu surların krokilerinin hazırlanması konusunda üst makamlarca birçok yazışma yapılmıştır. Ancak arşivde yapılan araştırmalarda bu krokilere rastlanılmamıştır. Surların eski eser olarak kabul edilmesi 19. yy'ın son dönemlerinde çıkarılan Asar-1 Attika Nizamnamelerinde geliştirilen eski eser ve koruma tanımlarıyla paralellik göstermektedir. Ancak bu bilincin henüz çok yeni olması sebebiyle surların krokilerinin hazırlanamadığ 1 anlaşılmaktadır.

Cumhuriyet dönemine Galata surlarından çok az kalıntı ulaşmış bulunmaktadır. Menderes dönemi öncesinde Galata surlarıyla ilgili ciddi müdahalelere rastlanmaktadır. Menderes yönetiminde yapılan istimlâkler ve geniş caddeler açılması için yapılan çalışmalarda, bu yolların güzergâhlarında kalan yapılar ortadan kaldırılmıştır. Galata surlarına ait olan bir burç, Kemeraltı Caddesi'nin genişletilmesi çalışması sırasında tamamen ortadan kaldırılmasa da büyük ölçüde zarar görmüştür.

Surların yıkım süreci 19. ve 20. yüzyılda oluşturulan bir takım haritalarda da gözlenmektedir. 1858-60 tarihli G. D'Ostoya 
haritas1 (Resim 12) Belediye Meclis

Mühendisi G. D'Ostoya tarafından hazırlanmıştır. Harita Galata, Pera, Taksim ve Pangaltı'nın mevcut durumunu gösteren detaylı bir çalışmadır ve Pera bölgesinin 1870 yangını öncesi durumunu gösterdiği için önemli bir yere sahiptir. Haritada, sadece Galata bölgesinin 1. dönem surlarının kuzey bölümündeki büyük bir kısım ile doğu bölümündeki surların eksikliği tespit edildiğinden bu tarihe kadar surların büyük ölçüde korunduğu anlaşılmaktadır.

1864 Marie de Launay haritasına göre (Resim 13) Galata surlar1 D'Ostoya haritasıyla oldukça benzerlik göstermektedir. Dış surların tamamına yakını ayakta durmakta, iç surlarda da bazı bölümler yok olmuştur.

Galata surları hakkında 1863 yılında alınan yıkım kararından yaklaşık 40 sene sonra hazırlanan Goad Haritas1 (Resim 14) sadece sokak ve konut dokusu hakkında bilgi vermeyen, aynı zamanda binaların kat adetleri ile yapım teknikleri ve kullanım durumları ile ilgili de bilgiler veren 1905 tarihli bir çalışmadır. Haritada Galata'da dış surların tamamına yakınının haritada mevcut olmadığı görülmektedir. Böylece 6. Daire tarafından 1863 yılında alınan yıkım kararı sonrasından 1905 tarihli Goad Haritası hazırlanana kadar geçen aradaki bu sürede surların büyük ölçüde yıkıldığı sonucu çıkarılmaktadır.

1944 tarihli Schneider-Nomidis haritasında (Resim 16) ise iç ve dış surlarda bir miktar daha yok olma durumu izlenmektedir.

Günümüze gelindiğinde ise Emekyemez Mahallesi'nde 1. ve 2. dönem surlarına ait olan yaklaşık 150 m.lik bir sur hatt1, bir kule ile bir kapı; Arap Camii Mahallesi'nde 1. döneme ait $44 \mathrm{~m}$. uzunluğunda kemer dizili bir sur duvarı, $28 \mathrm{~m}$. uzunluğunda 5. Döneme ait olan kitabeli bir sur duvarı, 1. Döneme ait farklı yapı adalarında yapı aralarına sıkışmış bazı duvar parçaları, kare planlı bir kule; Bereketzade Mahallesi'nde yer yer kesintiye uğrayan $200 \mathrm{~m}$. uzunluğunda 2. döneme ait iki burçlu bir sur hatt1, Galata Kulesi ve etrafındaki çevre duvar- larının büyük bir kısmı; Müeyyedzade Mahallesi'nde 6. döneme ait bir burç; Hac1 Mimi Mahallesi'nde Kemeraltı Caddesi kenarında bulunan 6 . döneme ait bir kule temeli; Kemankeş Kara Mustafa Paşa Mahallesi'nde de Yeraltı Camii'ni çevreleyen Galata Mahzeni'ne ait sur duvarı bulunmaktadir (Resim 26).

M2 metro hattının Şişhane'den Yenikapı'ya uzanan bölümünün 2014 yılında açılması ile birlikte Emekyemez Mahallesi'nde metro tünel çıkışı Galata surlarını tahrip etmiş durumdadır. Metro hatt1 uzatılmadan önce koruma kurulu tarafından istimlak edilen arasalarda ortaya çıkarılan surların rölöve, redtitüsyon ve restorasyon projelerinin hazırlanması gerektiği yapılan yazışmalarda görülse de sadece rölöveleri alınarak mimari belgelemeleri yapılmıştır. Surlar için restorasyon projeleri hazırlanmadan metro güzergahı uzatılarak sur duvarları içinden metro tüneli Emekyemez mahallesinden yer üstüne çıkmış ve surlar ağır bir tahribata uğramıştır. Kent dokusu arasında yüzyıllardan beri korunup günümüze kadar ulaşan surlar, şu an istimlak edilen arazinin ortasında hiç bir bakım ve koruma önlemi alınmadan açık bir şekilde durmaktadırlar. Bu surlarla birlikte yine dağınık biçimde kalan parçalarının ise gelecekteki durumları belirsizdir $\bullet$ 

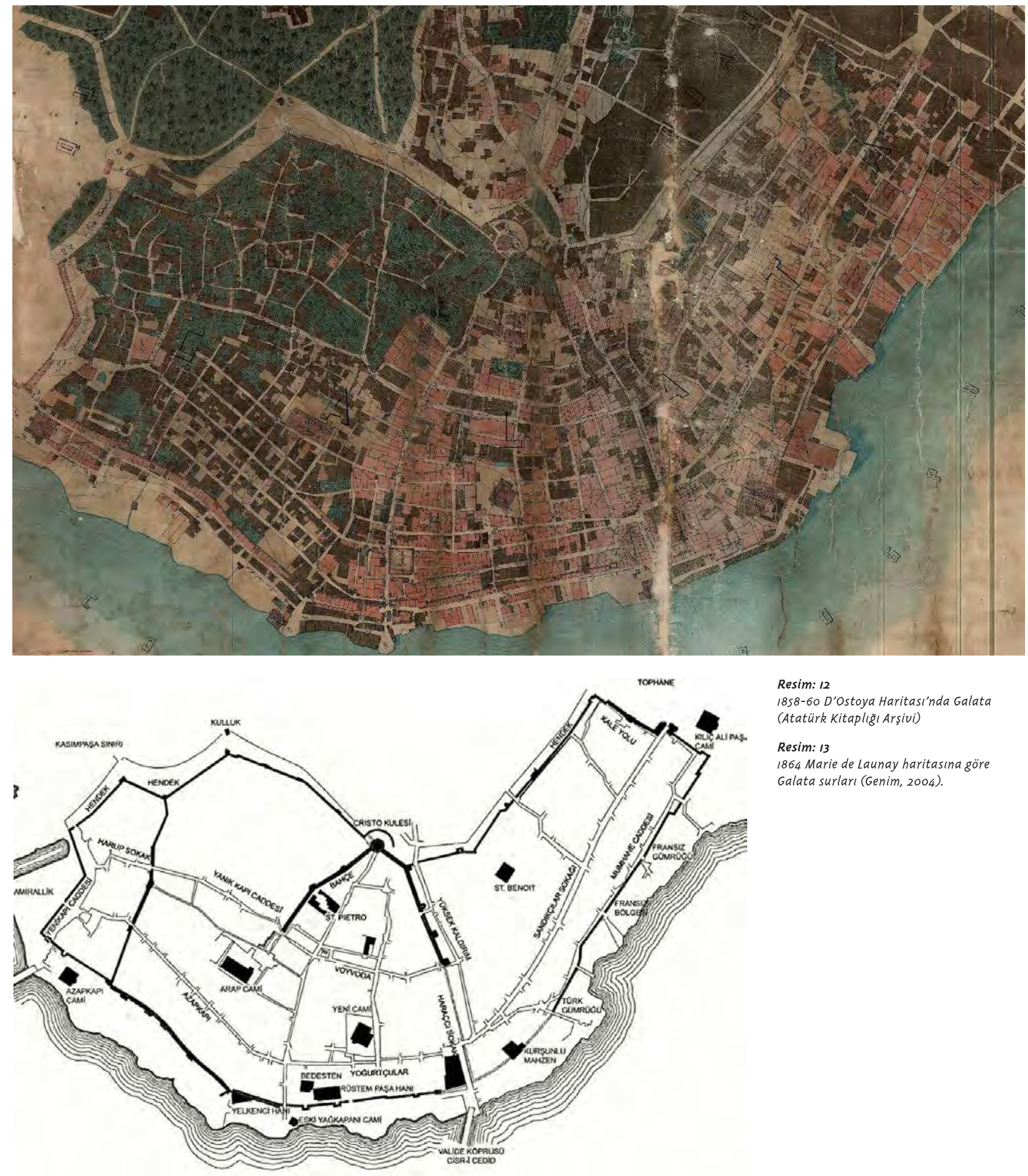

Resim: 12

1858-60 D'Ostoya Haritasi'nda Galata (Atatürk Kitaplığı Arşivi)

Resim: 13

1864 Marie de Launay haritasina göre Galata surları (Genim, 2004). 

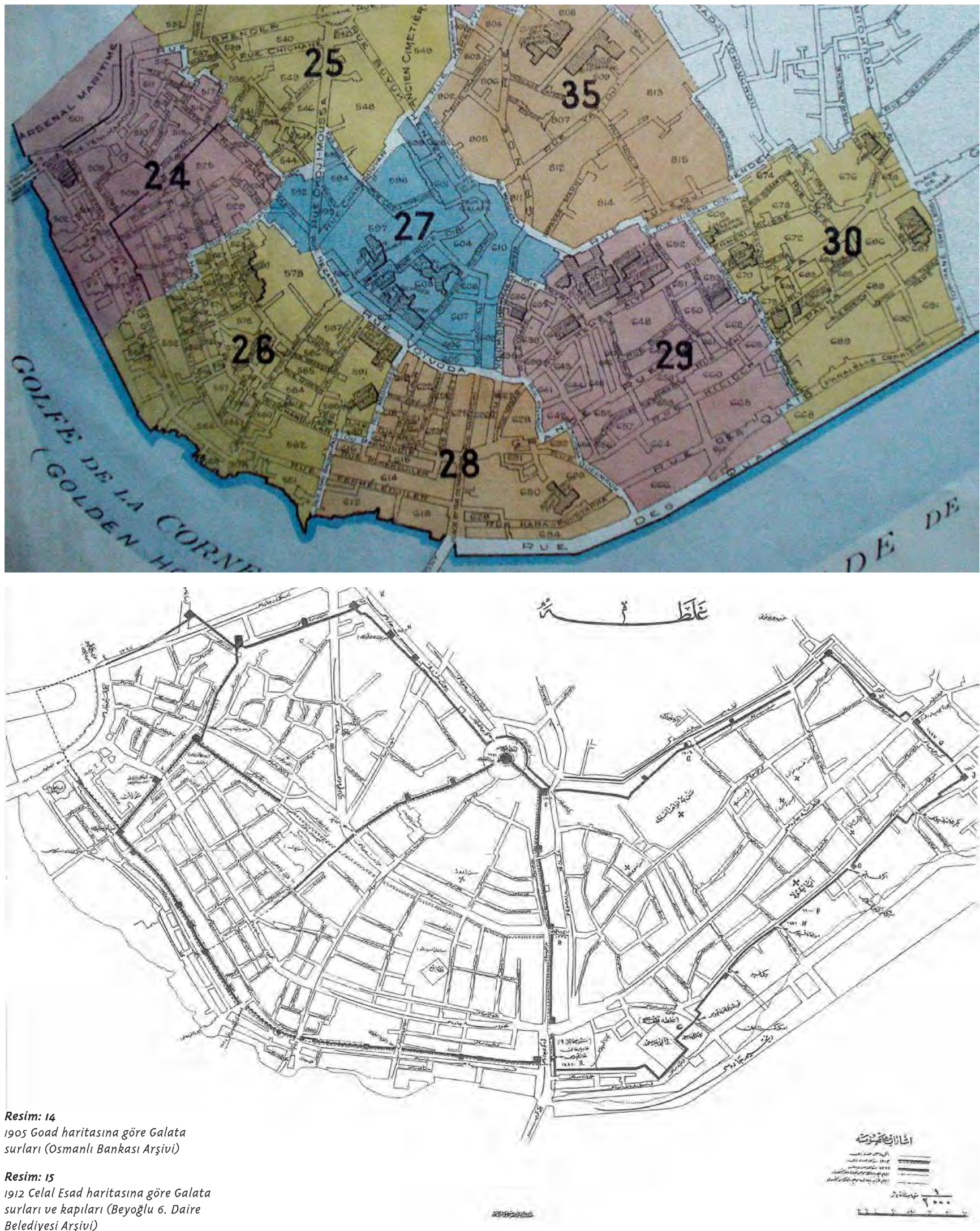

Belediyesi Arşivi) 

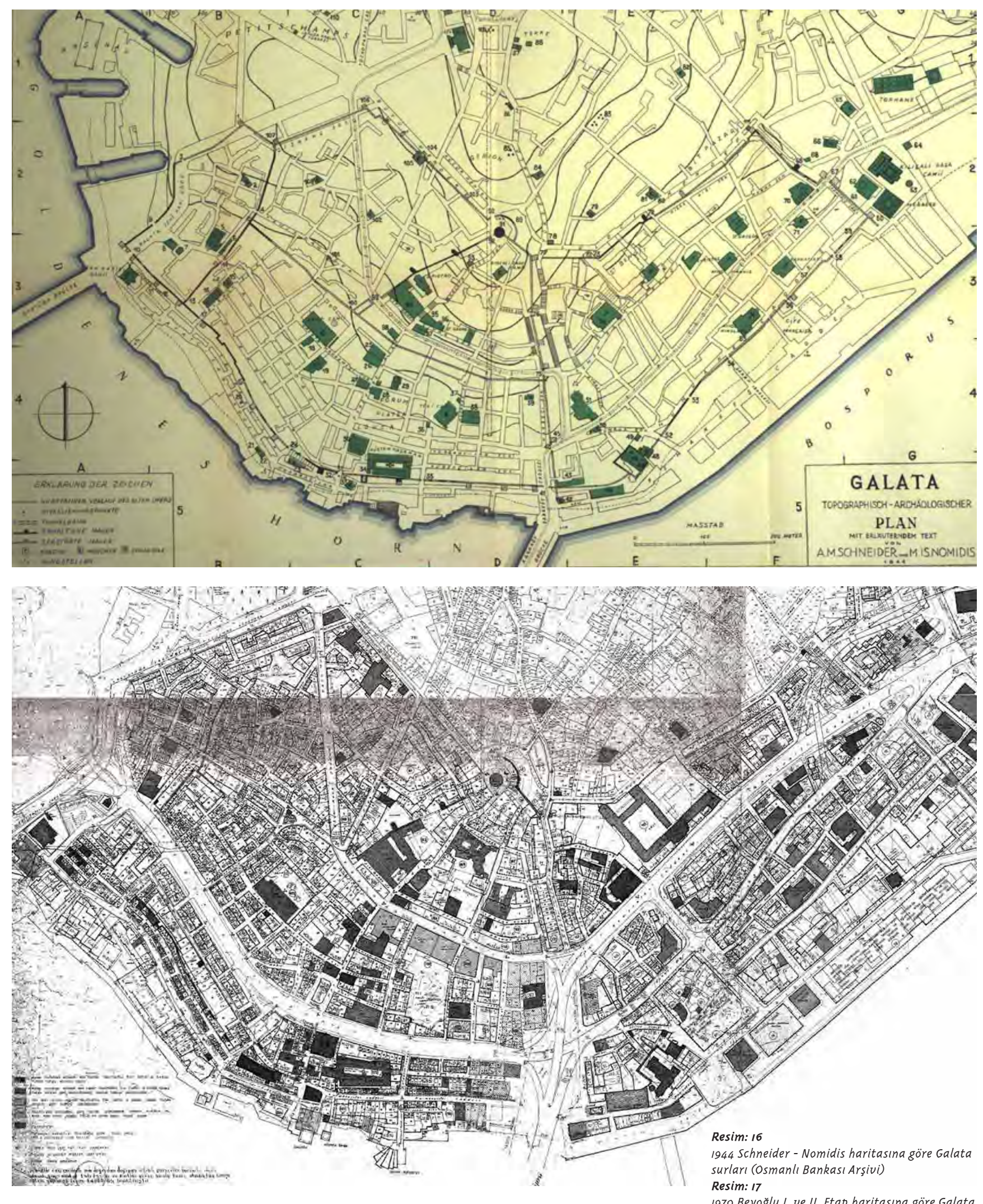
Resim: 18

Schneider-Nomidis (1944) haritası üzerine Beyoğlu halihazır haritasında tesbit edilen surların yerleştirilmesi (Düzenleme: Esra Okur coşkunçay)
Resim: 19

Schneider-Nomidis (1944) haritası üzerine 1858-60 D'Ostoya haritasinda tesbit edilen surların yerleştirilmesi (Düzenleme: Esra Okur coşkunçay)
Resim: 20

Schneider-Nomidis (1944) haritası üzerine 1864 Marie de Launay haritasinda tesbit edilen surların yerleştirilmesi (Düzenleme: Esra Okur coşkunçay)
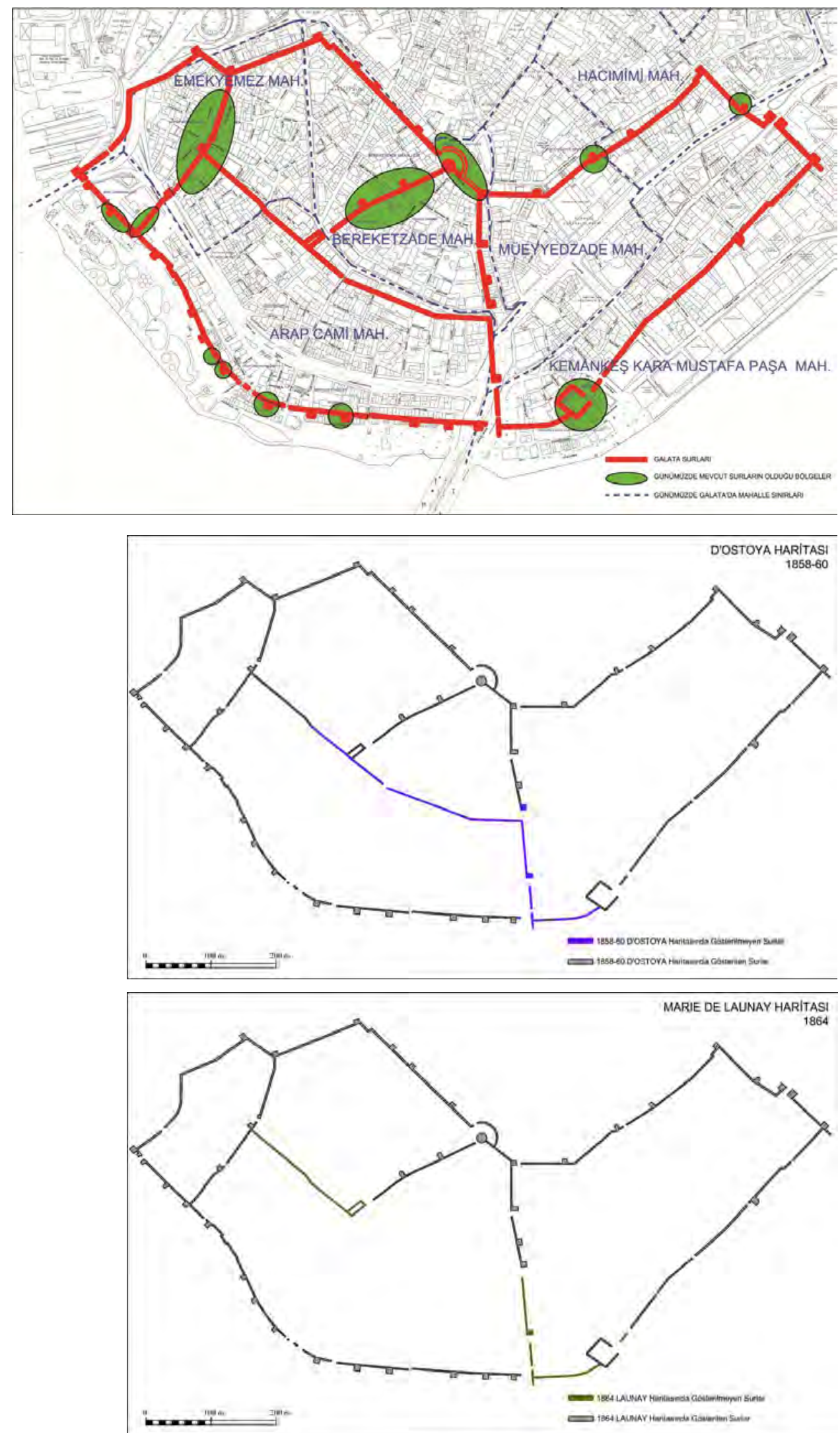

Sayı 25, Mayıs 2018 

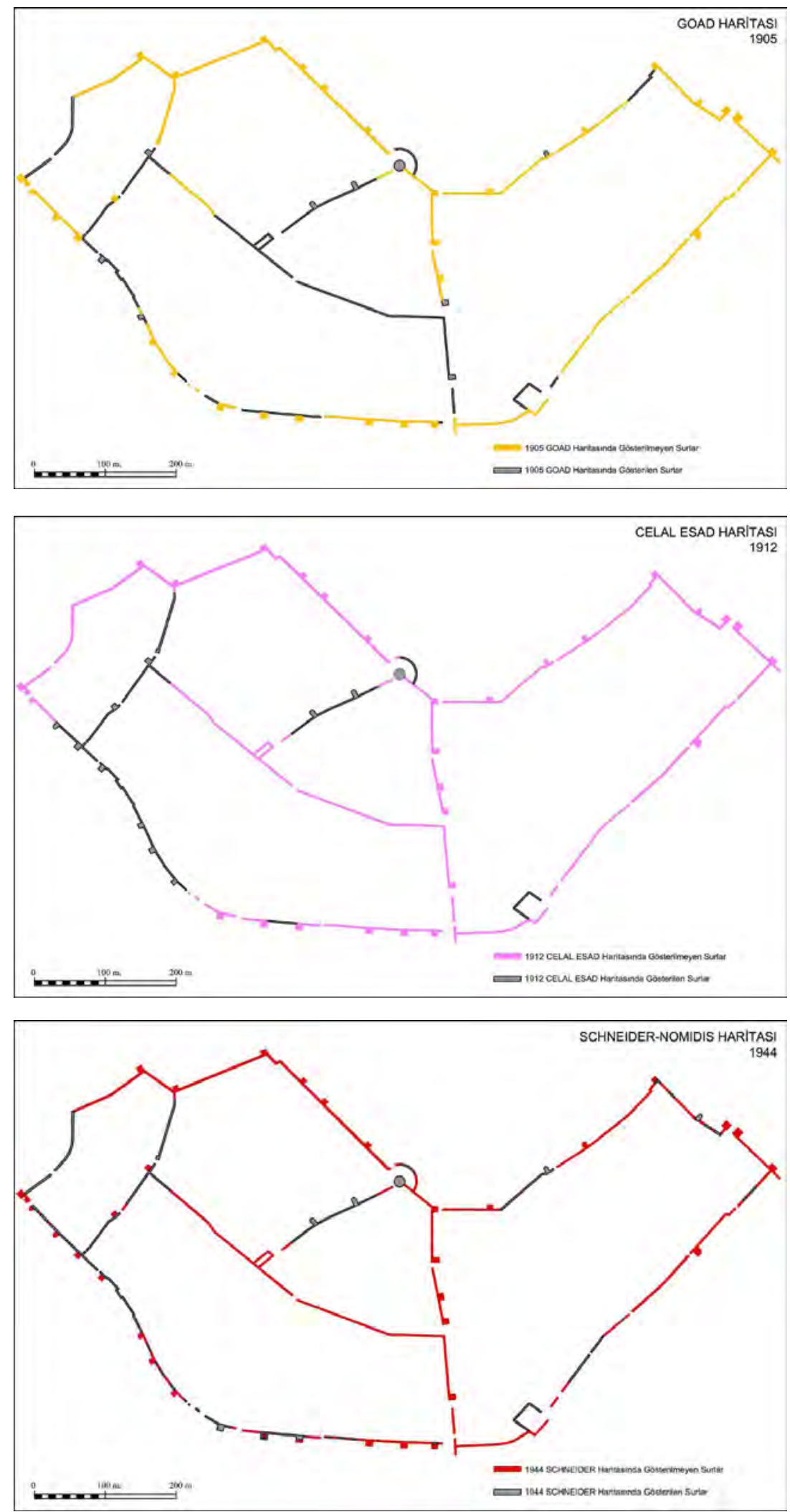

\section{Resim: 21}

Schneider-Nomidis (1944) haritası üzerine 1905

Goad haritasında tesbit edilen surlarin yerleşti-

rilmesi (Düzenleme: Esra Okur Coşkunçay)
Resim: 22

Schneider-Nomidis (1944) haritası üzerine 1912 Celal Esad haritasinda tesbit edilen surlarin yerleştirilmesi (Düzenleme: Esra Okur Coşkunçay)

\section{Resim: 23}

1944 Schneider - Nomidis haritasına göre tesbit edilen Galata surları (Düzenleme: Esra Okur coşkunçay) 
Resim: 24

Schneider-Nomidis (1944) haritası üzerine 1970 Beyoğlu I. ve II. Etap haritasinda tesbit edilen surların yerleştirilmesi (Düzenleme: Esra Okur coşkunçay)

Resim: 25

Schneider-Nomidis (1944) haritası üzerinde 2011 yılında mevcut Galata surları (Düzenleme: Esra OKUR (OSKUNÇAY)
Resim: 26

Schneider-Nomidis (1944) haritası üzerinde 1860 - 2011 yılları arasında Galata surlarınin yıkım süreci (Düzenleme: Esra Okur Coşkunçay).
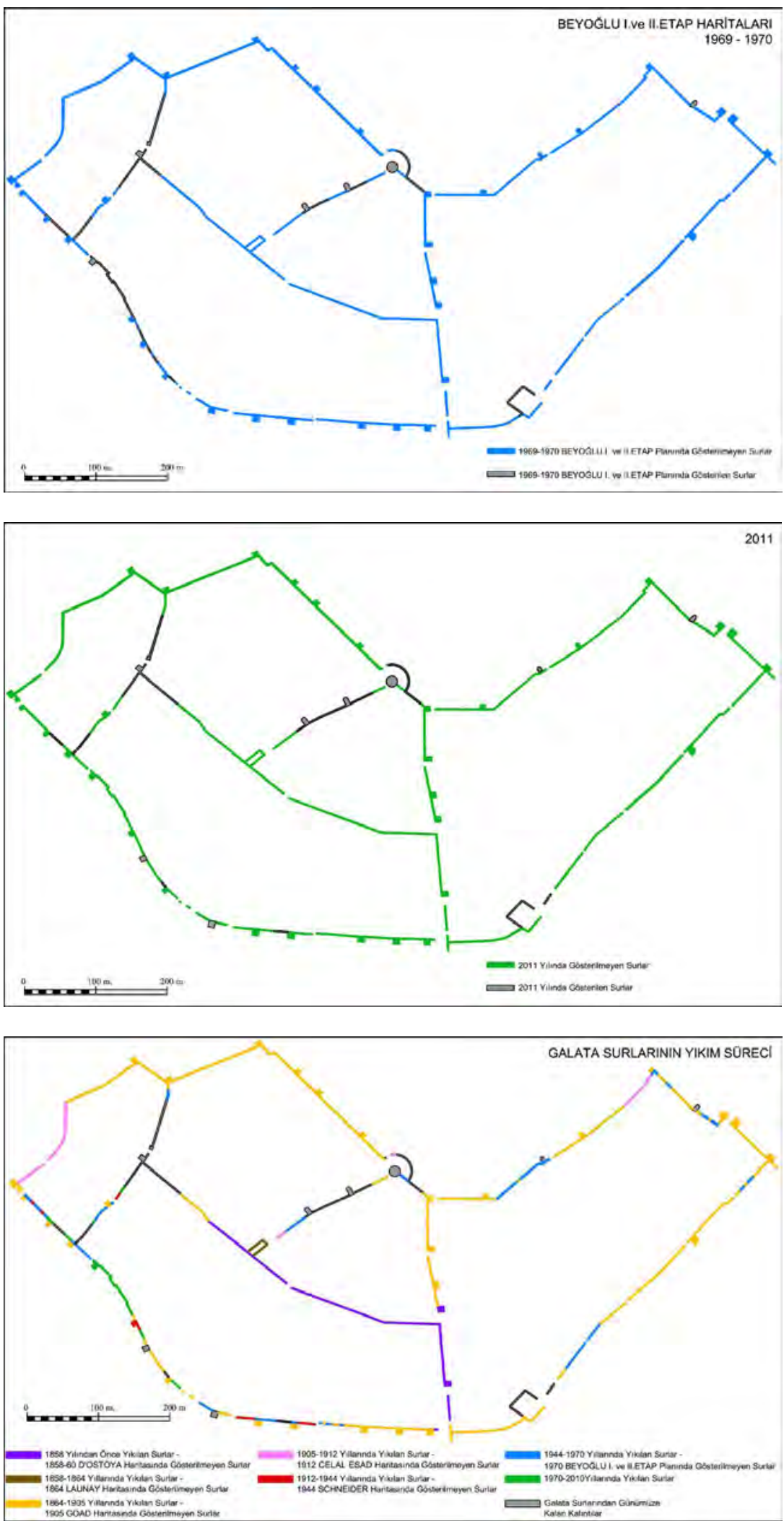


\section{Kaynakça}

Akın, N. 2002. 19. Yüzyılın İkinci Yarısında Galata ve Pera. İstanbul: Literatür Yayıncılık.

Aktepe, M.N. 1984. Vak'a-nüvis Ahmed Lutfî Efendi Tarihi. Ankara: Türk Tarih Kurumu Basımevi.

Bilsel, C. 2011. İmparatorluk'tan Cumhuriyet'e İstanbul'u Modernleștirme Projesi ve Prost Planı. Betonart (29): 43-48

Çal, H. 2005. Osmanlı'dan Cumhuriyete Eski Eserler Kanunları. Prof. Dr. Kazım Yaşar Kopraman'a Armă̆an, der. Yalçın, S., 234-270. Ankara: Berikan Yayınevi.

Çeçener, B. 1994. İstimlâkler. Dünden Bugüne Ístanbul Ansiklopedisi IV., der. Anonim, 272-275. İstanbul: Türkiye ve Ekonomik Toplumsal Tarih Vakfı.

Celik, Z. 1996. 19.yüzyılda Osmanlı Başkenti Değișen İstanbul. İstanbul: Türk Vakfı Yurt Yayınları.

Eyice, S. 1969. Galata ve Kulesi. İstanbul: Türkiye Turing ve Otomobil Kurumu.

Genim, M.S. 2004. Lygos, Bizantion, Konstantinopolis, Istanbul: Beyoğlu'nun Yerlessim Tarihi. Gecmişten Günümüze Beyoğlu cilt 1, 15-70. İstanbul: TAÇ Vakfı Yayınları.

Kuban, D. 2004. İstanbul Bir Kent Tarihi Bizantion, Konstantinopolis, İstanbul. İstanbul: Türkiye Ekonomik ve Toplumsal Tarih Vakfı.

Kuban, D. 1994. Menderes ve İstanbul. Dünden Bugüne İstanbul Ansiklopedisi V., 389-392. İstanbul: Türkiye ve Ekonomik Toplumsal Tarih Vakfı.

Launay, M.D. 1864a. Notice sur Les Fotifications de Galata Journal de Constantinople, 01.12.1864.

Launay, M.D. 1864b. Notice sur Les Fotifications de Galata, Journal de Constantinople, 02.12.1864.

Launay, M.D. 1864c. Notice sur Les Fotifications de Galata, Journal de Constantinople, 05.12.1864

Müller-Wiener, W. 2007. İstanbul'un Tarihsel Topografyası: 17. Yüzyıl Bașlarına Kadar ByzantionKonstantinopolis-İstanbul. İstanbul: Yap1 Kredi Yayınlar1.

Öncel, A.D. 2010. Apartman-Galata'da Yeni Bir Konut Tipi. İstanbul: Kitap Yayınevi.

Schneider ve Nomidis. 1944. Galata Haritası. İstanbul: Osmanlı Bankası Arsivi.

Toprak, Z. 1994. Altıncı Daire-i Belediye. Dünden Bugüne İstanbul Ansiklopedisi I, 220-223. İstanbul: Türkiye ve Ekonomik Toplumsal Tarih Vakfi.

Ünsal, 1969. İstanbul'un İmarı ve Eski Eser Kaybı. Türk Sanat Tarihi Arastırma ve Incelemeleri II, 5-60. İstanbul: Milli Eğitim Basımevi.

Boğaziçi Peyzaj İnşaat Müşavirlik Teknik Hizmetler San. ve Tic. A.Ş. - BIMTAŞ, 2009. Galata Emekyemez Mahallesi ve Arap Camii Mahallesi Haliç Metro Geçiş Köprüsü Projesi için çekilen fotoğraflar.

Boğaziçi Peyzaj İnșaat Müșavirlik Teknik Hizmetler San. ve Tic. A.Ş. - BIMTAŞ, 2009. Beyoğlu Yakası Tersane Caddesi Güney ve Kuzeyindeki Surların Rölövesi 30.12.2009.

İstanbul II Numaralı Kültür ve Tabiat Varlıklarını Koruma Bölge Müdürlüğü. 2010. İstanbul Metrosu Haliç Metro Geçiș Köprüsü Projesi Sunumu 12.02.2010.

\section{Başbakanlık Osmanlı Arşivi Belgeleri:}

Başbakanlık Osmanlı Arşivi. A.MKT.MHM. (Sadaret, Mühimme Kalemi Evrak1). Dosya No:309. Gömlek No:4

Başbakanlık Osmanlı Arşivi. A.MKT.MHM. (Sadaret, Mühimme Kalemi Evrak1). Dosya No:323.
Gömlek No:37

Başbakanlık Osmanlı Arșivi. A.MKT.MHM. (Sadaret, Mühimme Kalemi Evrakı). Dosya No:313. Gömlek No:61

Başbakanlık Osmanlı Arşivi. A.MKT.NZD. (Sadaret Mektubî Kalemi, Nezaret Ve Devâir Evrak1). Dosya No:334. Gömlek No:88

Başbakanlık Osmanlı Arşivi. BEO. (Bâb-1 Âlî Evrak Odas1). Dosya No:88. Gömlek No:6554

Başbakanlık Osmanlı Arşivi. BEO. (Bâb-1 Âlî Evrak Odası). Dosya No:126. Gömlek No:9382

Başbakanlık Osmanlı Arşivi. C.BLD. (Cevdet, Belediye). Dosya No:3. Gömlek No:114

Başbakanlık Osmanlı Arşivi. C.BLD. (Cevdet, Belediye). Dosya No:52. Gömlek No:2585

Başbakanlık Osmanlı Arşivi. C.BLD. (Cevdet, Belediye). Dosya No:53. Gömlek No:2620

Başbakanlık Osmanlı Arşivi. C.BLD. (Cevdet, Belediye). Dosya No:69. Gömlek No:3439

Başbakanlık Osmanlı Arşivi. C.BLD. (Cevdet, Belediye). Dosya No:134. Gömlek No:6675

Başbakanlık Osmanlı Arșivi. C.BLD. (Cevdet, Belediye). Dosya No:141. Gömlek No:7020

Başbakanlık Osmanlı Arşivi. DH.MKT. (Dâhiliye, Mektubi Kalemi). Dosya No:1. Gömlek No:77

Başbakanlık Osmanlı Arşivi. DH.MKT. (Dâhiliye, Mektubi Kalemi). Dosya No:1940. Gömlek No:18

Başbakanlık Osmanlı Arşivi. DH.MKT. (Dâhiliye, Mektubi Kalemi). Dosya No:1947. Gömlek No:112

Başbakanlık Osmanlı Arșivi. DH.MKT. (Dâhiliye, Mektubi Kalemi). Dosya No:2013. Gömlek No:47

Başbakanlık Osmanlı Arşivi. DH.MKT. (Dâhiliye, Mektubi Kalemi). Dosya No:2031. Gömlek No:53

Başbakanlık Osmanlı Arşivi. HAT. (Hatt-ı Hümayun). Dosya No:679. Gömlek No: 33114A

Başbakanlık Osmanlı Arşivi. HR.TO. (Hariciye Nezareti, Tercüme Odası). Dosya No:204. Gömlek No:64

Başbakanlık Osmanlı Arşivi. İ.DH. (İradeler, Dahiliye). Dosya No:452. Gömlek No:29957

Başbakanlık Osmanlı Arşivi. İ.DH. (İradeler, Dahiliye). Dosya No:531. Gömlek No:36789

Başbakanlık Osmanlı Arşivi. İ.DH. (İradeler, Dahiliye). Dosya No:1292. Gömlek No:101592

Başbakanlık Osmanlı Arşivi. İ.MVL. (İradeler, Meclis-i Vala). Dosya No:497. Gömlek No:22492

Başbakanlık Osmanlı Arşivi. İ.MVL. (İradeler, Meclis-i Vala). Dosya No:544. Gömlek No:24459

Başbakanlık Osmanlı Arșivi. MVL. (Meclis-i Vala). Dosya No:857. Gömlek No:82

Haritalar:

1858-60 D'Ostoya Haritası - Atatürk Kitaplığı Arşivi

1905 Goad Haritası - Osmanlı Bankası Arșivi

1944 Schneider - Nomidis Galata Haritası - Osmanlı Bankası Arşivi

1912 Celal Esad Galata Haritası - Beyoğlu 6. Daire Belediyesi Arşivi

1970 Beyoğlu I. ve II. Etap Haritaları - İstanbul Büyükșehir Belediyesi Arşivi

\section{Internet kaynaklar}

URL 1: http://arkeolojihaber.net/2014/06/13/galata-surlarindaki-son-kapi-da-kapandi/, erişim tarihi 15.03 .2018 